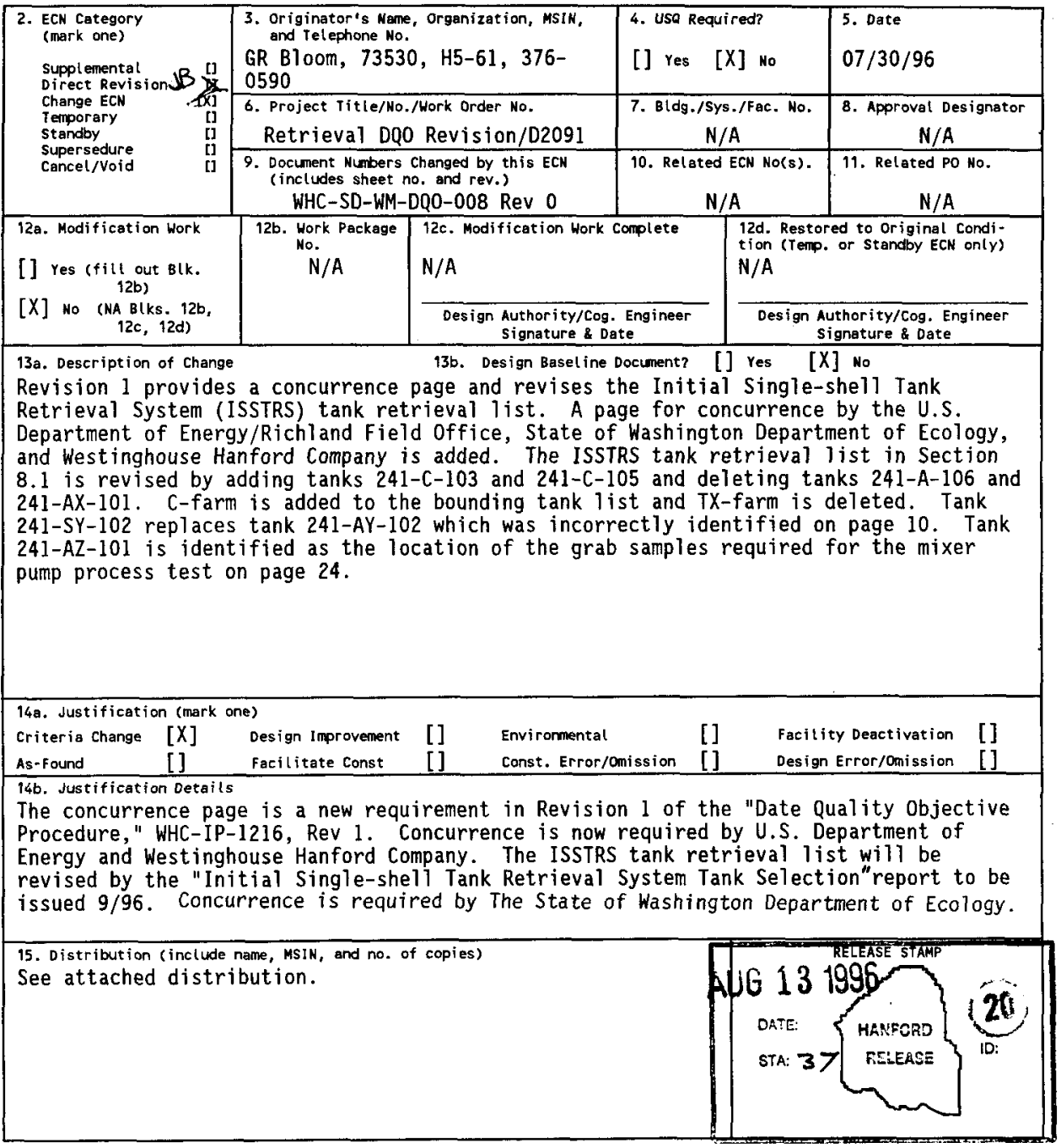

A-7900-013-2(05/96) GEF095 


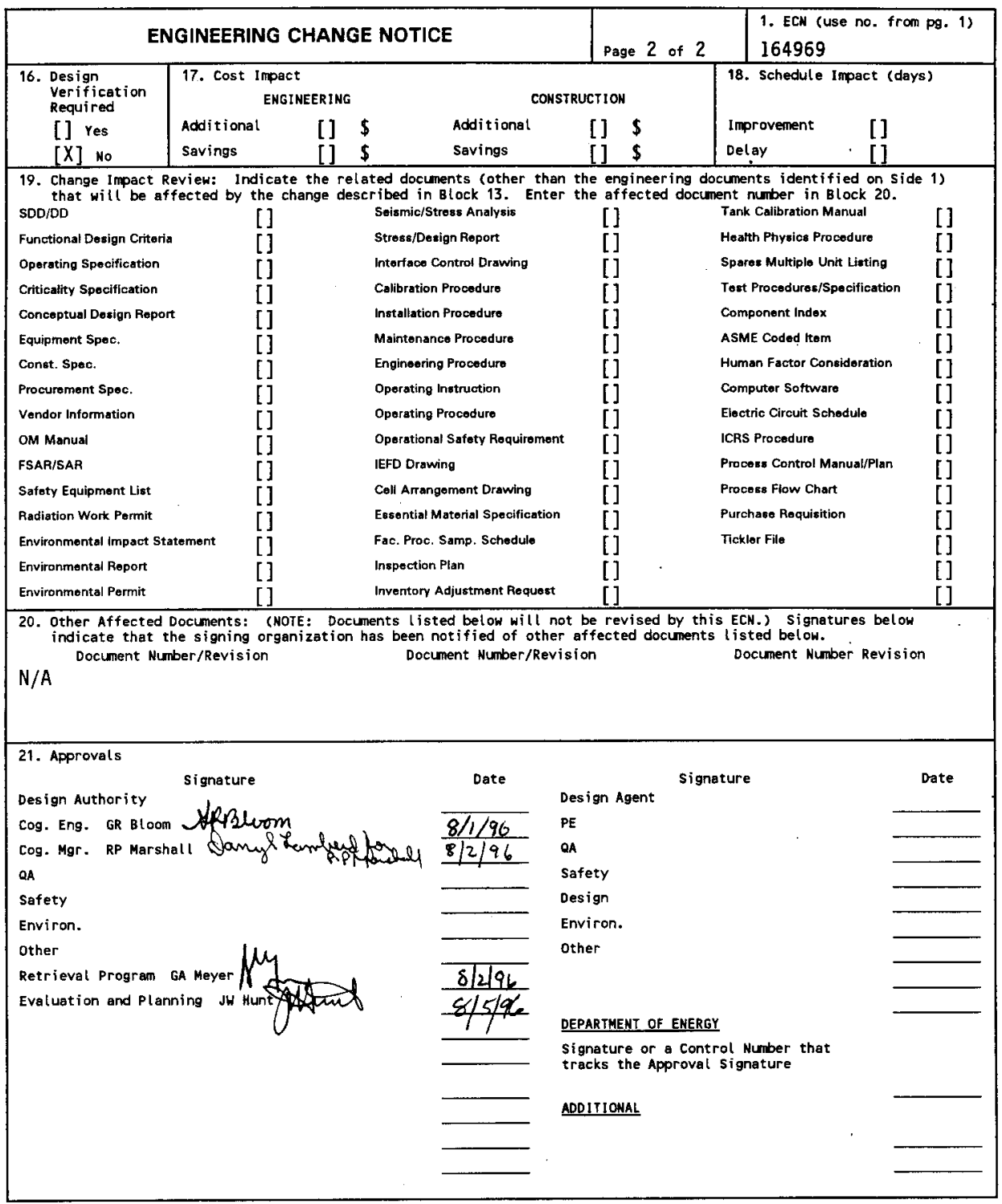




\section{Characterization Data Needs for Development, Design, and Operation of Retrieval Equipment Developed through the Data Quality Objective Process}

\section{Gerald R. Bloom}

Westinghouse Hanford Company, Richland, WA 99352

U.S. Department of Energy Contract DE-AC06-87RL10930

$\begin{array}{llll}\text { EDT/ECN: } & 164969 & \text { UC: } & 2000 \\ \text { Org Code: } & 73530 & \text { Charge Code: } & \text { D2091 } \\ \text { B\&R Code: } & \text { EW3130010 } & \text { Total Pages: } & 48\end{array}$

Key Words: DQO, retrieval

Abstract: This Data Quality objective identifies the specific characterization data required to support the development, design, and operation of systems to retrieve and transfer to storage waste from both single-shell tanks and double-shell tanks.

TRADEMARK DISCLAIMER. Reference herein to any specific comercial product, process, or service by trade name, trademark, manufacturer, or otherwise, does not necessarily constitute or itmply its endorsement, recomendation, or favoring by the United States Government or any agency thereof or its contractors or subcontractors.

Printed in the United States of America. To obtain copies of this document, contact: - WHC/BCS Document Contral Services, P.O. Box 1970, Mailstop $46-08$, Richland WA 99352, Phone (509) 372-2420; Fax (509) 376-4989.
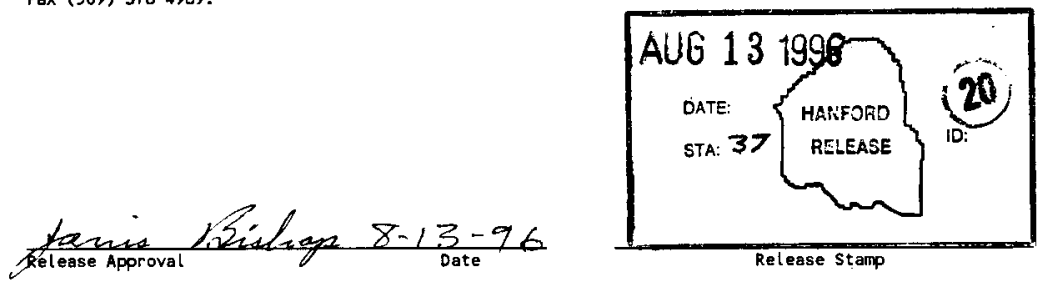

Release Stamp

\section{Approved for Public Release}




\section{RECORD OF REVISION}

(2) Title

Characterization Data Needs for Development, Design, and Operation of Retrieval

Equipment Developed through the Data Quality Objective Process

CHANGE CONTROL RECORD

\begin{tabular}{|c|c|c|c|}
\hline \multirow{2}{*}{ (3) Revision } & \multirow{2}{*}{ 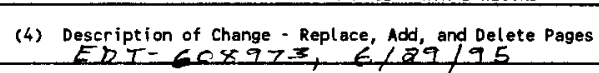 } & \multicolumn{2}{|c|}{ Authorized for Release } \\
\hline & & (5) Cog. Engr. & (6) Ggg. Mgr; Date \\
\hline $1 \mathrm{RS}$ & $\begin{array}{l}\text { (7) Concurrence page added and the ISSTRS } \\
\text { tank retrieval list revised }\end{array}$ & Sesherm & for 8 . $8 / 2 / 96$ \\
\hline 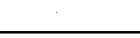 & $E C N-164969$ & GR Bloom & Rp Marshall \\
\hline & & & \\
\hline & & & \\
\hline & & & \\
\hline & & & \\
\hline & & & \\
\hline & & & \\
\hline & & & \\
\hline & & & \\
\hline & & & \\
\hline & & & \\
\hline & & & \\
\hline & & & \\
\hline & & & \\
\hline & & & \\
\hline & & & \\
\hline & & & \\
\hline & & & \\
\hline & & & \\
\hline & & & \\
\hline & & & \\
\hline & & & \\
\hline & & & \\
\hline & & & \\
\hline & & & \\
\hline & & & \\
\hline & & & \\
\hline & & & \\
\hline & & & \\
\hline & & & \\
\hline & & & \\
\hline & & & \\
\hline
\end{tabular}


Characterization Data Needs for Development, Design, and Operation of Retrieval Equipment Developed Through

the Data Quality objective Process

July 1996

G. R. B10om

Q. H. Nguyen 


\section{WHC-SD-HM-DQ0-008 REV 1}

\section{DATA QUALITY OBJECTIVE SIGNATURE PAGE}

The signatories on this page only concur with changes made to this document prior to the signature dates. The signatories shall be notified of all changes made to this document and this signature page should be updated when concurrence with the changes is obtained.
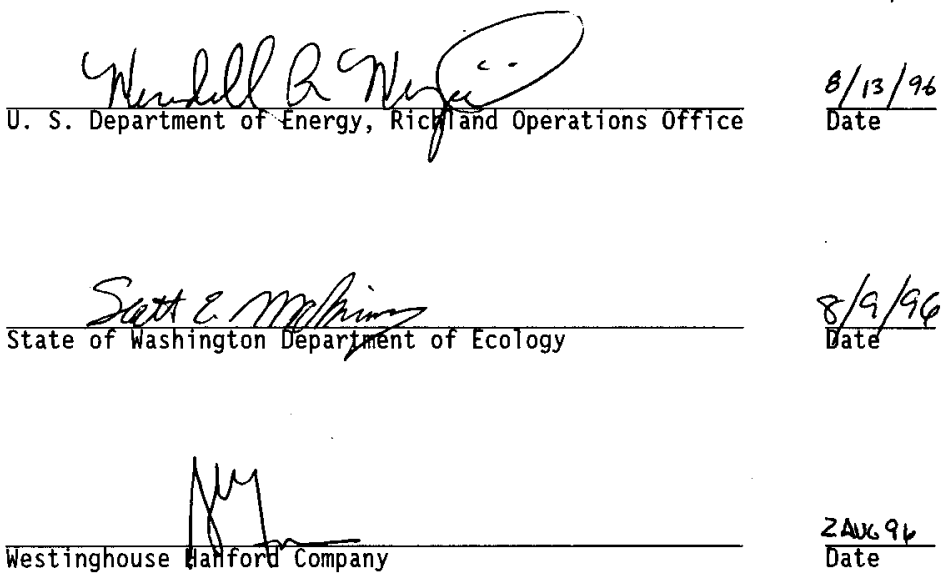

2Auc ar Date 
Contents

$1.0 \quad$ SUMMARY $\ldots \ldots \ldots \ldots \ldots$

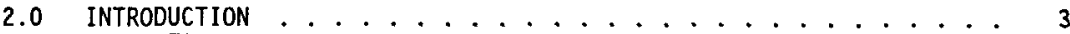

2.1 STRATEGY . . . . . . . . . . . 4

2.1 .1 SST Retrieval Strategy . . . . . . . . . 4

2.1 .2 DST Retrieval Strategy. . . . . . . . . . . 5

2.2 SCHEDULE ....................... 5

2.2 .1 SST Retrieval .............. 5

2.2 .2 DST Retrieval .............. . . 6

2.3 DATA QUALITY OBJECTIVE INTRODUCTION . . . . . . . 6

3.0 STATEMENT OF PROBLEM AND DECISION LOGIC ........... 7

3.1 STATEMENT OF PROBLEM ................ 7

3.2 RETRIEVAL DECISIONS . . . . . . . . . . 8

3.2 .1 SST Retrieval Decisions . . . . . . . . . 8

3.2 .2 DST Retrieval Decisions ........... 10

4.0 DECISION INPUTS . . . . . . . . . . . 11

4.1 SUMMARY OF DECISION INPUTS $\ldots \ldots \ldots \ldots \ldots$

4.2 ITEMS REQUIRING FURTHER RESOLUTION $\ldots \ldots \ldots \ldots$

4.2.1 Decision 1 - SST Retrieval Safety and Operational Considerations ................ 12

4.2.2 Decision 2 - Compatibility of Transfer Waste . . . . 12

4.2 .3 Decision 3 - Closure of SST ........ 12

4.2.4 Decision 4 - Design of an Alternate System ..... 12

4.2.5 Decision 5 - DST Retrieval Safety and Operational

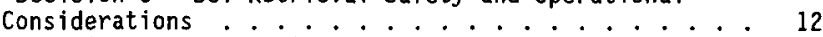

4.2.6 Decision 8 - Cross Site Transfer Requirement . . . 12

4.2.7 Decision 9 - Pretreatment Requirement ...... 16

5.0 DECISION RULE . . . . . . . . . . . . . 17

5.1 SUMMARY OF DECISION RULE $\ldots \ldots \ldots \ldots \ldots \ldots$

5.2 JUSTIFICATION OF DECISION THRESHOLD $\ldots \ldots \ldots \ldots$

6.0 ACCEPTABLE CONFIDENCE LIMITS FOR DECISION INPUTS . . . . . . 20

6.1 PHYSICAL BOUNDARIES OF DECISION INPUTS ......... 20

6.2 DECISION INPUT CONFIDENCE LIMITS ............. 21

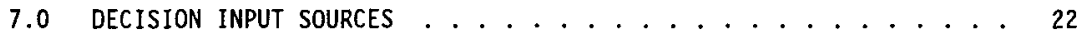

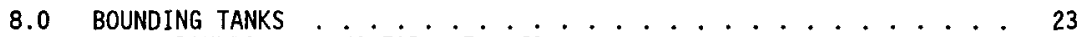

8.1 BOUNDING TANKS FOR SST DATA . . . . . . . . . . 23

8.2 BOUNDING TANKS FOR DST DATA . . . . . . . . . 24

9.0 IMPACT OF RETRIEVAL DECISIONS . . . . . . . . . . . 25

10.0 DATA PRIORITY . . . . . . . . . . . . . . 26

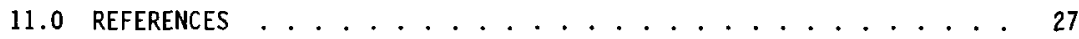


APPENDIX A: MOBILIZATION TECHNOLOGY DESCRIPTIONS . . . . . . . . A-1

APPENDIX B: DESIRED TANK WASTE INFORMATION FOR DST RETRIEVAL . . . . B-1

APPENDIX C: INFORMAL COST AND SCHEDULE INFORMATION ........c-1

\section{LIST OF FIGURES}

3-1. Initial SST to DST Retrieval Functions and Decisions ....... 13 3-2. DST Demonstration and Initial Retrieval Functions and Decisions . . 14 A-1. SST Sluicing Operating Scenario ............... A-2

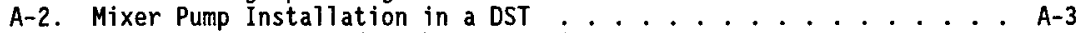
A-3. Operation Scenario for the Pneumatic Conveyance System . . . . A-6 A-4. Waterjets With Air Conveyance System . . . . . . . . . A-7 A-5. Scarifier Operating Scenario . . . . . . . . . . . A-8 A-6. Confined sluicing . . . . . . . . . . . . A-9

\section{LIST OF TABLES}

1-1. Summary Table of Data Requested . . . . . . . . . . 2

4-1. Summary of SST and DST Retrieval Input Decisions . . . . . 15

5-1. Decision Rules for Retrieval Operation . . . . . . . . . 18

5-2. Justification of Decision Threshold .............. 19

6-1. Physical Boundaries for Decision Inputs . . . . . . . . . 20

6-2. Tolerance Requirement for Decision Inputs . . . . . . . . . 21

$7-1$. Decision Input Sources ............... 22

9-1. Impact of Retrieval Decisions . . . . . . . . . . . . 25

A-1. Alternate System Data Needs - Scarifier Using Waterjet ..... A-10

A-2. Alternate System Data Needs - Convey \& Transport ......... A-11

A-3. Alternate System Data Needs - Waterjets ......... A-12

B-1. Desired Tank Waste Information for DST Retrieval Project . . . B-1 


\section{Characterization Data Needs for Development, Design, and Operation of Retrieval Equipment Developed Through the Data Quality Objective Process Summary}

\subsection{SUMMARY}

This Data Quality Objective (DQO) identifies the specific characterization data required to support the development, design, and operation of systems to retrieve and transfer to storage waste from both single-shell tanks (SSTs) and double-shell tanks (DSTs).

A summary of this data required to support initial planning and the early phases of design, including the key decisions it supports, is given in Table 1.1. The major decisions that require this data can be summarized as:

Definition of the minimum number of mixer pump(s) required to achieve satisfactory sludge mobilization. This will be defined through limited verification of the equations for effective cleaning radius (ECR) that have been developed using scale model testing.

Determination of what conditioning is required to transfer both SST and DST waste slurries.

Additional data identified in other DQO's, specifically Tank Farms Waste Compatibility, Flammable Gas, and Tank Waste Pretreatment and Disposal, are also required as indicated in the discussions of SST and DST decisions in Section 3 and in Appendix B.

It should be noted, that as system engineering requirements are developed and specific projects identified, their design and safety documentation process may require additional data that could result in the need for additional characterization, depending upon the state of knowledge at the time and the degree of accuracy required for the specific design, safety or operational feature. 
Table 1-1. Summary Table of Data Requested

\begin{tabular}{|c|c|c|c|c|c|c|c|}
\hline Decision & $\begin{array}{l}\text { Decision } \\
\text { Inputs }\end{array}$ & Why ${ }^{(1)}$ & Reason for Requesting & Boundary & Input sources ${ }^{(2)}$ & $\begin{array}{l}\text { Decision } \\
\text { Threshold }\end{array}$ & $\begin{array}{l}\text { Justification of decision } \\
\text { threshold }\end{array}$ \\
\hline \multirow[t]{4}{*}{$\begin{array}{l}\text { Is waste } \\
\text { ready for } \\
\text { transfer? }\end{array}$} & $\begin{array}{l}\text { Slurry } \\
\text { Density }\end{array}$ & op & $\begin{array}{l}\text { slurry density must be } \\
\text { low enough to prevent } \\
\text { solids settling in the } \\
\text { pipe. }\end{array}$ & \multirow{4}{*}{$\begin{array}{l}\text { Within } 3 \text {-inch } \\
\text { piping of the } \\
\text { recirculation } \\
\text { loop. }\end{array}$} & $\begin{array}{l}\text { 1. In situ mass/flow density } \\
\text { meter } \\
\text { 2. In situ ultrasonic sensor } \\
\text { 3. Grab sample }\end{array}$ & \multirow[t]{2}{*}{$\begin{array}{l}\text { Calculated } \\
\text { Reynolds } \\
\text { number } \\
\geq 20,000\end{array}$} & \multirow{2}{*}{$\begin{array}{l}\text { Reynolds number above } 20,000 \\
\text { assures turbul ent flow of } \\
\text { waste. Data needs for } \\
\text { calcul at ing the Reynolds } \\
\text { number are waste density, } \\
\text { viscosity, pipe diameter and } \\
\text { pump vel ocity (Fowler } 1995 \text { ). }\end{array}$} \\
\hline & viscosity & op & $\begin{array}{l}\text { Viscosity must be low } \\
\text { enough to assure pump } \\
\text { will provide } \\
\text { sufficient flow. }\end{array}$ & & $\begin{array}{l}\text { 1. In situ viscometer } \\
\text { 2. Grab sample }\end{array}$ & & \\
\hline & Temp. & Ds & $\begin{array}{l}\text { 1. Temperature of } \\
\text { slurries must be } \\
\text { within the design } \\
\text { range. } \\
\text { 2. Slurry temperature } \\
\text { must exceed lower } \\
\text { pumpability limit (see } \\
\text { Compatibility DoO). }\end{array}$ & & 1. Thermocouple & $\begin{array}{l}\text { Temperature } \\
>\text { saturat ion } \\
\text { temperature } \\
\text { of waste }\end{array}$ & $\begin{array}{l}\text { Transfer temperature must be } \\
\text { above the saturation } \\
\text { temperature of the waste so } \\
\text { that no precipitation or } \\
\text { gelation will form during } \\
\text { transfer (Fouler 1995). }\end{array}$ \\
\hline & $\begin{array}{l}\text { Volume } \\
\text { Percent } \\
\text { Solids }\end{array}$ & Op & $\begin{array}{l}\text { Percent sol ids must be } \\
\text { low enough to prevent } \\
\text { plugging pipe. }\end{array}$ & & $\begin{array}{l}\text { 1. In situ sensor } \\
\text { 2. Grab sample }\end{array}$ & $\begin{array}{l}\text { Volume } \\
\text { Percent } \\
\text { Solids }<30 \\
\text { volz }\end{array}$ & $\begin{array}{l}30 \text { vol } \% \text { is a design parameter } \\
\text { for the cross site transport } \\
\text { line. Hithout proper } \\
\text { dilution. Waste can settle and } \\
\text { plug pipes (Kal ia 1995). }\end{array}$ \\
\hline \multirow{3}{*}{$\begin{array}{l}\text { Is mobil ized } \\
\text { sludge volume } \\
\text { predicted by } \\
\text { ECR } \\
\text { equations? }\end{array}$} & $\begin{array}{l}\text { Shear } \\
\text { strength }\end{array}$ & $\begin{array}{l}\text { Ds } \\
\text { op }\end{array}$ & $\begin{array}{l}\text { Settled sludge removal } \\
\text { is dependent on shear } \\
\text { strength (based on the } \\
\text { current ECR equation). }\end{array}$ & $\begin{array}{l}\text { In-tank: } \\
\text { With in the } \\
\text { settled sludge } \\
\text { layer }\end{array}$ & $\begin{array}{l}\text { 1. In situ Shear vane } \\
\text { 2. Cone penetrometer } \\
\text { 3. Core sample }\end{array}$ & \multirow{3}{*}{$\begin{array}{l}\text { Predicted } \\
\text { mobilized } \\
\text { volume must } \\
\text { be with in } \\
\text { actual } \\
\text { volume } \pm 20 \%\end{array}$} & \multirow{3}{*}{$\begin{array}{l}\text { The predicted nobitized volume } \\
\text { percent must be within } 20 x \\
\text { observed in order to } \\
\text { differentiate between proposed } \\
\text { ECR equations proposed by PNL } \\
\text { (Gates and Beckette 1995). }\end{array}$} \\
\hline & $\begin{array}{l}\text { Sludge } \\
\text { profile }\end{array}$ & op & $\begin{array}{l}\text { sludge profile will be } \\
\text { used to verify the ECR } \\
\text { equation. }\end{array}$ & $\begin{array}{l}\text { In-tank: } \\
\text { Measure sludge } \\
\text { layer at the } \\
\text { bottom of } \\
\text { tank. } \\
\end{array}$ & $\begin{array}{l}\text { 1. In si tu ultrasonic sensor } \\
\text { 2. Gamma sensor } \\
\text { 3. Temperature profile from } \\
\text { thermocouple tree } \\
\text { 4. Manual profile measurement }\end{array}$ & & \\
\hline & $\begin{array}{l}\text { slurry } \\
\text { density }\end{array}$ & op & $\begin{array}{l}\text { Determination of } \\
\text { suspended slurry is an } \\
\text { indication of settled } \\
\text { sludge mobilized. }\end{array}$ & $\begin{array}{l}\text { In-tank: } \\
\text { Measure within } \\
\text { waste tank } \\
\text { slurry layer. }\end{array}$ & $\begin{array}{l}\text { 1. In situ turbidity sensor } \\
\text { and grab sample }\end{array}$ & & \\
\hline
\end{tabular}

(1) Ds: Design, Op: Operation

(2) Sources are listed with most desirable method on top 


\subsection{INTRODUCTION}

The 149 SSTs are arranged in 12 farms of 4 to 18 tanks each and contain three general waste forms: sludge, saltcake, and liquid. Sludge consists of the solids (hydrous metal oxides) precipitated from the neutralization of acid wastes. Saltcake consists of the various water soluble salts formed by the evaporation of water from the alkaline waste. Liquids exist as supernatant and interstitial liquid in the tanks. These waste forms are intermingled to differing degrees. Many SSTs contain both sludge and saltcake, with a wide range of ratios in this combination. Some sludges and saltcake contain interstitial liquids and are relatively soft. Other tanks have saltcake and sludge which is drier and harder, and a few have dried to brick-like hardness.

The 28 DSTs are arranged in farms of 2 to 8 tanks each and contain mostly liquids and sludges with a small amount of saltcake in some of the tanks. The notable exception is 241-SY-101 which is full of saltcake slurry. Four of the 28 DSTs contain high level, first cycle solvent extraction from plutonium-uranium extraction (PUREX) plant. The remaining 24 DSTs are designed to store lower-heat waste and contain varying amounts of sludge, saltcake, supernate, evaporator feed and concentrated liquid waste. Most sludge is located in 16 of the DSTs with the remainder containing liquids and less than $2.54 \mathrm{~cm}$ (1 inch) of sludge. Retrieval of the waste in tanks with only supernate is expected to be relatively easy if compatibility and solubility of the supernate are controlled.

The retrieval strategy is to remove waste with reference equipment, assess impacts of the residual waste and if necessary use alternate technologies to remove enough waste to meet tank site closure requirements. Reference mobilization are the mixer pump for DST waste and past-practice sluicing for SST waste. Alternate methods, which include those identified through the Acquired Commercial Technologies for Retrieval (ACTR) program, will be used to retrieve waste from SSTs or DSTs if past-practice sluicing or mixer pumps do not meet waste mobilization requirements.

This DQO addresses waste information needs for retrieval equipment design, development, and operations, including determination of waste compatibility for transfer operations. Tank waste characterization data will be obtained for retrieval operations after the waste tank retrieval sequence has been determined.

Waste retrieval requires tank waste characterization data to, (1) assure safe and compatible waste transfer operations, (2) determine the reference mixer pump design equation and verify if one mixer pump is adequate to retrieve DST waste, (3) provide process control information to assure proper transfer conditions during use of the cross site transfer pipe, and (4) development and selection of alternate retrieval systems. 


\section{WHC-SD-WM-DQO-008 REV 1}

\section{$2.1 \cdot$ STRATEGY}

The Tank Waste Remediation System (TWRS) Program Mission is to store, treat, and immobilize the highly radioactive Hanford Site waste in a safe, environmentally sound and cost effective manner.

Waste Retrieval provides systems for the mission which resolve tank safety issues; remove waste from aging SSTs and transfer to DSTs for safe interim storage; mobilize sludge in DSTs for in-tank treatment or transfer; provide for transfer of wastes for consolidation in DSTs or to treatment and immobilization facilities.

The Waste Retrieval strategy to accomplish this mission utilizes the following key elements.

- SST waste removal is based on past practice sluicing.

- DST waste removal is based on mixer pumps to mobilize waste.

- Enhancements are anticipated in areas such as reduced exposures, extended equipment service life and reuse capability.

- Alternate retrieval methods will be developed and used as needed for wastes which cannot be retrieved by the above proven technical methods.

\subsubsection{SST Retrieval Strategy}

The SST Retrieval strategy is to begin with known technology, hydraulic sluicing, which has been successfully used for the retrieval of wastes in the 1950 s and 1960 s.

- Continue Project $W-320, C-106$ sluicing as planned to support TPA Milestone M-45-03A.

Sluicing will mobilize as much saltcake and sludge present as possible and if any tank waste remains it will be assessed on a tank-by-tank basis to determine final waste removal requirements. There are a variety of waste types and compositions, presence of hard heels, presence of in-tank hardware, and a potential for leakage from SSTs which may have to be considered. Consequently, enhancement and alternate methods will be selected that have greater capability for removing stubborn waste and to not rely on 7 arge volumes of liquid to retrieve wastes from the SSTs.

- Develop a program to solicit commercial techniques that could be applied to the retrieval of the non-stuicable wastes from $\mathrm{C}-106$ and for other non-sluicable items. 


\subsubsection{DST Retrieval Strategy}

The strategy for DST retrieval is to use rotating mixer pumps to mobilize and a transfer pump to convey waste from the underground tank as the reference approach based on their successful implementation at the Savannah River Site and the West Valley Demonstration Project. The following presents the major aspects of this strategy.

- Demonstrate full scale mixer pump performance by Project W-151 which demonstrates mobilization of actual sludge in tank DST 241$A Z-101$ (AZ-101) using two 300-horsepower mixer pumps,

- Develop advanced mixer pump design based on improvements, enhancements, operational experience, and testing,

- Implement mixer pumps in DST Retrieval Project $W-211$ which retrieves waste from the first 10 DSTs to resolve safety issues and provide receiver tanks for SST waste, and

- Evaluate alternate methods in the event that mixer pumps cannot remove some of the more difficult DST wastes. Candidates include those being evaluated and developed for SST retrieval,

\subsection{SCHEDULE}

\subsubsection{SST Retrieval}

The baseline retrieval program plan calls for retrieval of all 149 SSTs as defined in TPA Milestone M-45-05, by September 2018. The initial retrieval sequence for SSTs is required for submittal to Washington State Department of Ecology by September 1996. The retrieval sequence for all 149 SSTs is being developed and SST retrieval plans will meet the shorter term retrieval requirements/tank selections. The SST retrieval TPA milestones are as follows.

M-45-03A--Initiate sluicing retrieval of C-106 by October 1997,

M-45-03-T02--Initiate final retrieval demonstration of $\mathrm{C}-106$ by June 2002. This demonstration will retrieve the remaining wastes that sluicing leaves behind, with the goal of $99 \%$ retrieval,

M-45-04-T01--Provide Initial SST Retrieval System by November 2003. This is defined as retrieval of an entire SST farm or an equivalent number of tanks. Sub milestone M-45-04A requires completion of a Conceptual Design for this retrieval system by Apri1 1997, and

M-45-05--Retrieve waste from all remaining SSTs by September 2018. The first two sub-milestones T01 and TO2 call for initiation of waste retrieval from one SST by December 2003 and two SSTs by September 2004, respectively. Additional sub-milestones cover the remaining tanks beginning in 2005 . 


\subsubsection{DST Retrieval}

Mixer pump and sludge wash demonstration of a DST is planned for tank 241-AZ-101 and is scheduled for September 1996. Measurement of sludge shear strength by an in situ sensor is required prior to the test to confirm the effective cleaning radius correlation for predicting mixer pump performance.

Project $W-211$ which retrieves the first 10 DSTs is reviewing its retrieval schedule which calls for initiation of retrieval of the first DST by 1999. The order for the first advanced design mixer pumps for the project will be placed in early FY 98 . The ECR equation must be verified and the range of shear strength for the initial tanks to be retrieved must be measured and used to determine the number of mixer pumps required by early FY 98 . Data are required to determine the number of mixer pumps required to mobilize waste in tanks 241-AW-105 and 241-SY-102.

\subsection{DATA QUALITY OBJECTIVE INTRODUCTION}

The role of the retrieval $D Q 0$ is to be an interface control document between TWRS Characterization and Retrieval Programs. The DQO process is utilized to ensure that retrieval data requirements are identified, sufficient, justified, and of adequate quality to support design, development and operations of retrieval equipment required to complete the retrieval mission. This $D Q 0$ process and report include information required by the TWRS Characterization Program for planning sampling and analys is of tank waste. The format followed for decision inputs in this DQO was that recommended by TWRS Characterization (Kelley 1994) in the example draft DQO "Data Requirements for the Ferrocyanide Safety Issue Developed through the Data Quality Objectives Process," December 1994.

The seven steps of the DQO planning process are listed below.

1. Define the problem.

2. Define desired decision(s).

3. Define decision input(s).

4. Define boundaries.

5. Determine decision rule $(s)$.

6. Determine decision errors.

7. Optimize sampling approach.

An initial Retrieval DQO process was completed by following the DQO process steps as described above. Steps 1 through 5 of the DQO process were completed through retrieval DQO meetings. Steps 6 and 7 were partially addressed through discussion with Westinghouse Hanford Company and Battelle Pacific Northwest Laboratory personnel. It was determined in the final two steps that much of the initial data requested had insufficient justification. A revision of the Retrieval DQO was necessary to redefine the problem, to focus the decisions, and to provide clearer justification for needed tank waste information. Steps 1 through 5 of the DQO process were repeated with additional $D Q O$ meetings, private consulting, discussions with project managers and key personnel in the retrieval projects. The outcome of these meetings resulted in more project specific data requirements. Better definitions of decision logics, decision inputs, decision boundaries and decision rules were achieved. Data measuring error tolerances requirements were also addressed in 
the report "Identification of Physical Properties for the Retrieval Data Quality Objective Process" (Gates and Beckette 1995). Step 7 Optimization of the sampling approach is initiated in this DQO and will be completed by the TWRS Disposal Program and TWRS Characterization utilizing a Disposal Program Sampling Strategy and other sampling data optimization methods.

Other DQOs have been prepared by related programs which will be utilized when applicable by the retrieval program. Waste data required to safely store waste is defined under the Tank Safety Screening and Safety Issue DQOs as part of the Safety and Characterization Program. Data required for safety and operational considerations for transfer of waste to/from a DST are addressed by the Tank Farms Compatibility DQO (Fowler 1995) covered under the Tank Farm Operation and Maintenance Program Office. The TWRS Disposal Program includes the retrieval program which identifies retrieval information needs in this Retrieval $\mathrm{DQO}$ and the Pretreatment $\mathrm{DQO}$. The pretreatment and vitrification information needs are identified in the Tank Waste and Pretreatment $D Q O$ (Kupfer 1995). This work is provided by the Pretreatment, Low-Level Waste Disposal, and High-Level Waste Disposal program offices.

\subsection{STATEMENT OF PROBLEM AND DECISION LOGIC}

\subsection{STATEMENT OF PROBLEN}

The successful retrieval of waste from SSTs and DSTs requires that acceptable safety, health and operational conditions must be assured. Retrieval systems equipment must be adequately designed and developed to cost effectively manage these risks.

The TWRS remediate tank waste functions which must be performed, and the requirements which must be met in performing those functions, are documented (DOE/RL 1994). The functional decomposition of the TWRS Functions and Requirements is currently in review. Remediate tank waste is a level two function which covers level three functions of manage tank waste and process tank waste. Level four functions under process waste include the retrieval tank waste function. Characterize waste is a level four function under manage tank waste.

This Retrieval DQO defines and documents the waste characterization data to be provided by the Characterize Waste function to support the Retrieval Program. The Characterize Waste function has both a characterization needs input from Retrieval and a characterization data output back to Retrieval. The Retrieval $D Q 0$ is an interface control document for the appropriate characterization data.

Schematic diagrams of the SST and DST retrieval processes, showing the overall retrieval functions and where major decisions and questions are addressed, are given in Figures 3-1 and 3-2. These questions, identified through the $\mathrm{DQO}$ process with regard to waste retrieval equipment design, development, and operations that require tank waste characterization data, are as follows (decisions are identified in figures 3-1 and 3-2). 


\section{WHC-SD-WM-DQ0-008 REV 1}

- Is the retrieval system equipment adequate for the waste to be retrieved (Decisions 1 and 5 )?

- Does the waste being considered for transfer meet the waste compatibility requirements for safety and operations (Decisions 2 and 7$)$ ?

- Is mobilized sludge volume predicted by ECR equation? (Decision 6)?

- How much dilution is required before transferring mobilized waste (Decisions 2, 7 and 8 )?

- Does the waste meet pretreatment receiving requirements (Decision 9)?

- Is sufficient waste removed to meet closure requirements (Decision 3)?

- Which alternate retrieval method is required to remove the waste (Decision 4)?

\subsection{RETRIEVAL DECISIONS}

This section identifies the decision logic needed to successfully and safely retrieve SST and DST wastes. The term "decision" used in this context represents the check points or decision points that required tank waste information to proceed. Figures 3-1 and 3-2 show schematic diagrams for the SST and DST retrieval processes. Decisions requiring waste characterization information are identified with a dotted line between the function or decision block (represented by a rectangle or diamond shape respectively) and the decision criteria are listed.

\subsubsection{SST Retrieval Decisions}

The Initial Single-Shell Tank Retrieval System (ISSTRS) project includes engineering evaluations and hazard analysis on the tanks selected for retrieval as part of the project process. The ISSTRS project selects the tanks to be retrieved in coordination with pretreatment and safety programs. This initial set of tanks is selected based on the compatibility of source tank waste with the destination DST, operational safety issues, cost, tank nonleakage, amount of waste in the tanks, and availability of transfer lines. Tank waste compatibility from the source and receiving tank is analyzed at this step and therefore no "conditioning", other than dilution, should be necessary before conveying diluted waste to a DST receiving tank. The information requirements to assure compatible waste transfer operations are provided (Fowler 1995). Tank selection criteria and evaluation is not included in the scope of this DQO. 
The selected SST reference retrieval equipment is past-practice sluicing. Implementation data needs have been met through historical tank waste data and will be further supported with documentation of past experience. Review of available characterization data will provide additional confidence in the design and operation of the sluicing equipment. Such tank waste data can be obtained through historical records and documents (Brevick 1995a,b,c). Past experience will be obtained by consulting with experienced operators or workers. Information from sluicing operations, such as installation of saltwells for pumping liquids and thermocouple trees to measure waste temperatures, will provide confirmation that the saltcake can be sluiced. The thermocouple tree installation process involves the use of a mini waterjet, or force insertion of hollow tubing, to break up the waste.

The safety analysis for the ISSTRS provides a safety evaluation which is prepared during conceptual design of the sluicing equipment. A final Safety Analysis Report is prepared prior to initiation of retrieval operations and includes sluicing equipment design and retrieval operation safety assessments. Hazards of retrieval operations, including an assessment of the potential for criticality, release of noxious gases (such as ammonia) and triggering a release of flammable gases will be evaluated and the need for any mitigation equipment identified for the tanks to be retrieved. Accumulation of fiammable gas during waste storage is addressed in the Flammable Gas DQO (Johnson 1995) and some information is available for watch list tanks.

The SST tank symbol in Figure 3-I represents deployment of the first SST retrieval equipment after project design. Deployment includes installation of the retrieval system components and support functions, operational checkouts, and demonstration of operational readiness. The support functions include ail equipment necessary for the operation of the retrieval system components, including utilities, service piping, monitoring and control equipment, personnel and equipment facilities.

Reconfirmation of source and receiver tank waste compatibility will be made after the deployment of the ISSTRS equipment in an SST. Prior to transfer, tank waste compatibility data is needed to assure transfer operations meet safety and operational criteria after waste mobilization.

Saltcake and/or sludge waste is resuspended by breaking up the material into particles and dissolving some saltcake or suspending sludge and saltcake in an aqueous solution, such as a slurry. An aqueous stream is utilized for conveyance. Mobilization may involve resuspension or dissolution of the waste depending on solubility and saturation state of the liquid used in mobilization. Conveyance is the transfer of the SST waste to a DST holding tank.

Prior to transfer of an SST slurry to a receiving DST, the pumpability of mobilized waste must be considered. Slurry not meeting the transfer requirements will be diluted with water or an alkaline solution to provide waste meeting transfer requirements. Other chemical or physical conditioning should not be necessary as this was addressed during the tank selection process. Data needs for the pumpability decision are the properties to calculate Reynolds number, temperature and solids concentration. Proposed in situ instruments would measure flow, density, viscosity, and temperature to determine the pumpability of waste. A volume percent solids instrument is 
proposed for development to provide an in situ measurement to assure that the volume of solid waste is below 30 percent.

Decision 3, shown after SST conveyance, represents the evaluation which is performed to assess if waste remaining in the SST meets closure requirements. Closure requirements will be addressed by a future closure DQO. After as much of the mobilized waste is removed from the tank as possible, the remaining waste, objects, and in-tank hardware will be assessed to determine completion of mobilization. If the remaining waste exceeds the allowable limit after sluicing, the remaining waste will be evaluated and a decision made for further retrieval.

Should it be determined that additional waste removal is required which is beyond the capability of sluicing methods, an alternate mobilization system will be required. The selection, design, development, and operation of alternate systems to mobilize and convey the hard-to-retrieve waste will involve decisions which may require further waste characterization. These decisions identified for the alternate program are described in Appendix A.

\subsubsection{DST Retrieval Decisions}

Figure 3-2 shows the DST retrieval functions and decisions addressed which need waste characterization information. DST retrieval functions are similar to SST retrieval functions as discussed in the previous section, except in two areas, 1) the verification of the reference system (i.e., the mixer pump) and 2) waste transfer can either be to a pretreatment plant or to the cross site transfer system.

The DST retrieval sequence was previously determined for the initial DST Retrieval System, Project W-211. The DSTs identified for retrieval by Project W-211 (Rieck 1995) will change, as a consequence of changed priorities. Currently, the two highest priority tanks for retrieval by Project $W-211$ are tanks 241-SY-102 and 241-AW-105. The remaining tanks to be retrieved will be determined by the new retrieval sequence. Tank waste compatibility between the source tank and the receiving tank or process plant is confirmed before transferring the waste.

The selected reference retrieval system for DSTs is the mixer pump for mobilization and transfer pump for conveying purposes. Project W-151 Mixer Pump Demonstration will confirm the mixer pump performance and provides the opportunity to validate an empirical model estimating the effective cleaning radius (ECR) of the mixer pump. Two sets of constants have been proposed for the ECR model (Appendix A). Confirmation of the ECR model requires in situ measurement of sludge shear strength to predict sludge mobilization and provide a basis for the determination of correct ECR model constants. The ECR equation would be confirmed by comparing the predicted mobilized volume of sludge to the observed mobilized volume after mobilization with the mixer pumps. In situ measurements of sludge shear strength and slurry density are required. If the ECR model is confirmed, the equation with the valid constants will be used to determine the number of mixer pumps required for a specific tank, based on waste information. If both proposed equations fail to predict sludge mobilization adequately, the data obtained will be used to define new work to resolve the issue. 
Project $W-211$ is the retrieval of waste in the first 10 DSTs and is currently in the Title I phase of detailed design. A Hazards Analysis and Preliminary Safety Evaluation (Kidder 1994) are complete and a Safety Assessment is in process. Potential hazards during retrieval operations such as criticality, release of noxious gas such as ammonia, and release of accumulated flammable gases are considered in these safety reviews and documents. The need for retrieval systems equipment to ensure safe operations and identification of critical design information will be determined during project design. Data provided by tank characterization reports, tank content estimates (Brevick 1995a,b,c), Agnew's model (Agnew 1994), and the Tank Waste Pretreatment and Disposa1 DQO (Kupfer 1995).

Installation of 2 mixer pumps is the current design basis for retrieval of DSTs for Project $W-211$. Significant savings (Appendix $B$ ) can be achieved by the reduction of 1 mixer pump wherever possible. Mixer pump demonstration testing of 2 standard mixer pumps on DST 241-AZ-101 (Koh1man 1993) wil1 confirm the design equation that will be used to determine the number of mixer pumps.

Requirements for confirmation of compatibility of source tank waste to be transferred with the receiving tank waste are provided by the Tank Waste Compatibility DQO (Fowler 1995). The requirement for turbulent flow of waste in the transfer line is the same as discussed earlier in the SST retrieval scenario. Presently, waste conditioning involves dilution to prepare waste for transfer. When waste is to be transferred to the pretreatment facility, waste feed requirements for the pretreatment plant or vitrification may impose additional acceptance criteria. No pretreatment requirements have been identified at this time. When waste is to be transferred to the cross site transfer system, waste parameters must be within design limits of the transfer system (Kalia 1994).

\subsection{DECISION INPUTS}

\subsection{SUMMARY OF DECISION INPUTS}

In the previous section, the decision logics that form the basis for the SST and DST retrieval design and operation were outlined. Characterization data input were identified for functions or decisions. Decision inputs consist of tank waste data, criteria or information that are needed to resolve a specific decision. Table 4-l summarizes decision statements, decision inputs and reason for requesting decision inputs. Decision numbers are also listed for referencing SST and DST retrieval decisions (Figures 3-1 and 3-2). 
WHC-SD-WM-DQO-0OB REV 1

\subsection{ITEMS REQUIRING FURTHER RESOLUTION}

\subsubsection{Decision 1 - SST Retrieval Safety and Operational Considerations}

The ISSTRS will address safety and operation decisions and determine the tank waste characterization requirements. The four main activities from the ISSTRS project are design, safety analysis, regulatory permitting and fire hazard analysis. The Compatibility DQO (Fowler 1995) will be utilized in the selection of the SST sequence and provide inputs to the four major activities of the project.

\subsubsection{Decision 2 - Compatibility of Transfer Waste}

Tank waste type of the mobilized source tank and receiver tank will be determined prior to transfer, as the source waste compatibility may change from the dilution during the mobilization process. The compatibility of wastes in tanks was considered during the tank selection process of the project. However, it is necessary to confirm compatibility of the actual mobilized waste prior to transfer. Tank waste type from the source tank retrieval waste will be determined and checked against waste type from the receiving tank using the waste type compatibility matrix (Fowler 1995).

\subsubsection{Decision 3 - Closure of SST}

Tank closure criteria is outside the boundary of this DQO and has not been addressed. A separate $D Q 0$ for closure of waste tank sites will determine the closure information requirements.

\subsubsection{Decision 4 - Design of an Alternate System}

Various commercially available retrieval systems will be selected and made available by the ACTR program. Tank waste information needed to develop these alternate systems and the properties of interest are given in Appendix A. No high priority project design decisions were identified which justified new sampling and analysis. Historical tank waste information, past experience, and data identified for other programs will be utilized by the alternates and ACTR program.

\subsubsection{Decision 5 - DST Retrieval Safety and Operational Considerations}

A preliminary list of desired tank waste characterization information for DST retrieval projects have been identified by the Initial Tank Retrieval Systems Project $W-211$ as shown in Appendix B (Van Beek 1995). The requested tank waste information is being addressed to provide justification, decision thresholds, confidence $1 \mathrm{imit}$ and input sources.

\subsubsection{Decision 8 - Cross Site Transfer Requirement}

Waste transfers must meet cross site requirements in addition to the pumpability requirements (Fowler 1995). Transfer waste must be within the design limits (Kalia 1994). Tank waste properties and their corresponding acceptance criteria will be determined prior to cross site transfer operations. Cross site transfer requirements are more critical due to longer transfer distance, higher pressure, and flow velocity. 


\section{WHC-SD-WM-DQ0-008 REV 1}

\section{Figure 3-1. Initial SST to DST Retrieval Functions and Decisions}

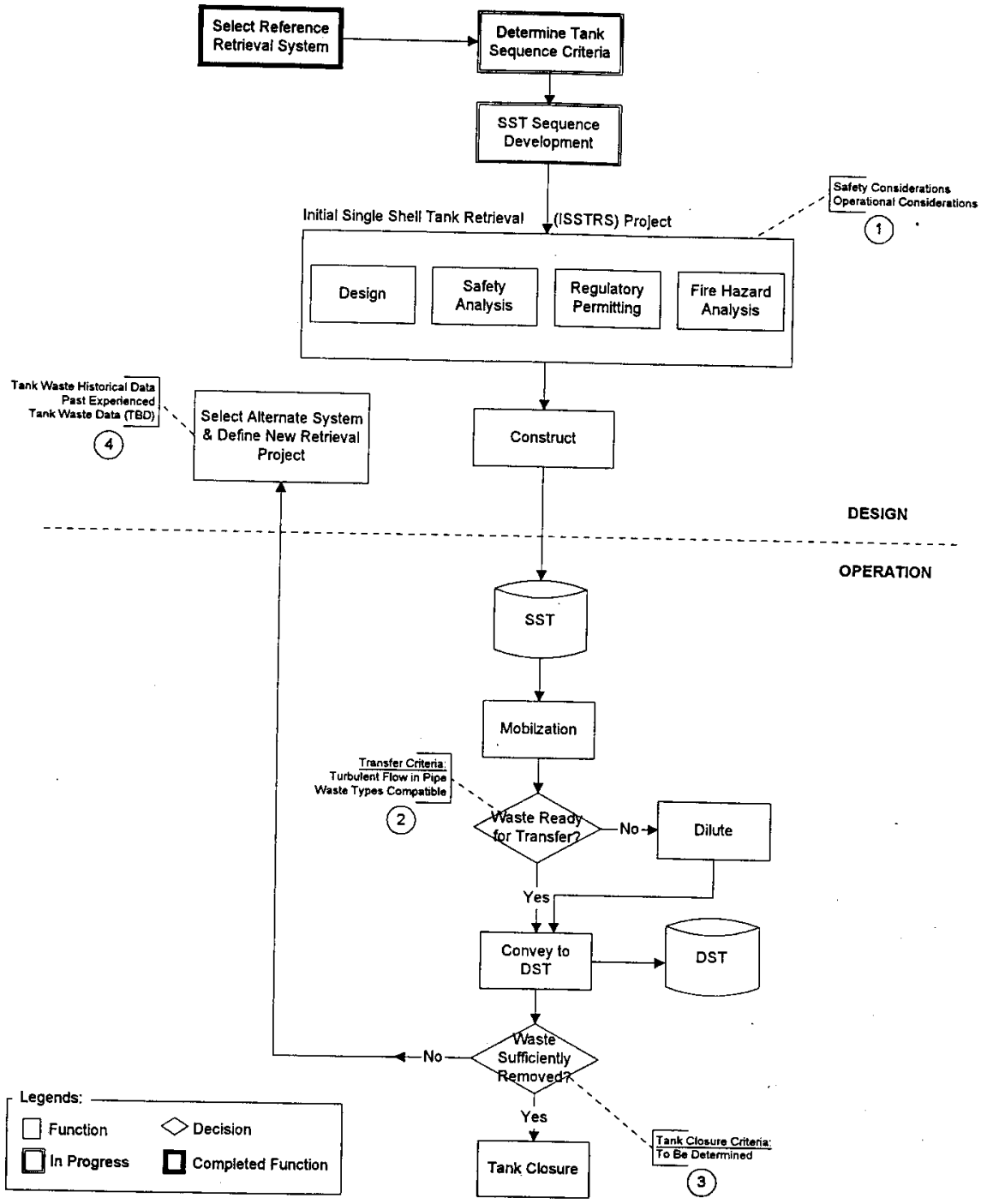


Figure 3-2. DST Demonstration and Initial Retrieval Functions and Decisions

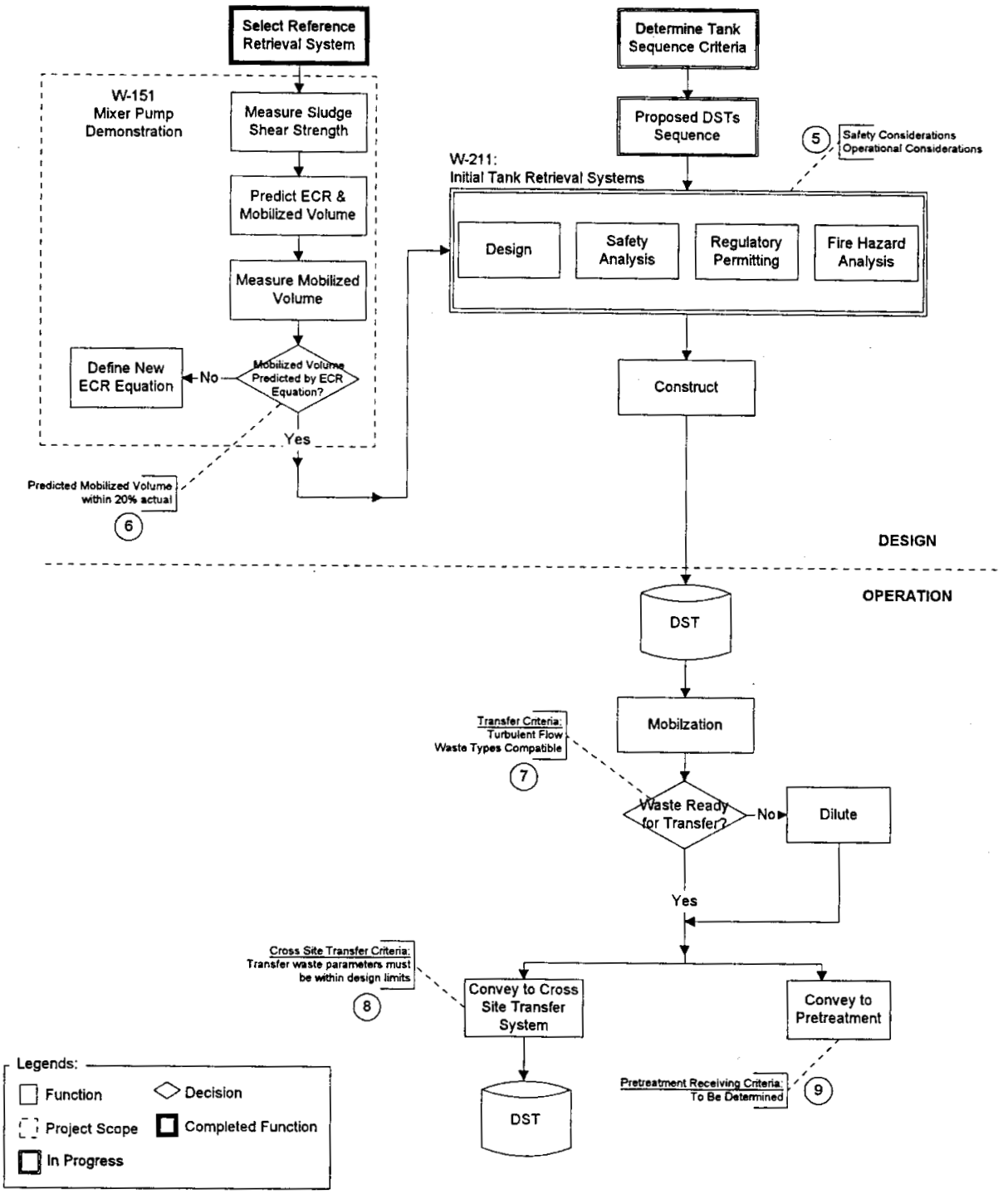


WHC-SD-HN-DQO-008 REV 1

Tab1e 4-1. Summary of SST and DST Retrieval Input Decisions

\begin{tabular}{|c|c|c|c|}
\hline $\begin{array}{l}\text { Dec. } \\
\text { No. }\end{array}$ & Decision & Decision Inputs & $\begin{array}{l}\text { Reason for Requesting } \\
\text { Decision Inputs }\end{array}$ \\
\hline 1 & $\begin{array}{l}\text { Is the retrieval } \\
\text { system equipment } \\
\text { adequate for the } \\
\text { waste to be } \\
\text { retrieved? }\end{array}$ & See Section 4.2 .1 & \\
\hline \multirow[t]{5}{*}{2} & \multirow[t]{4}{*}{$\begin{array}{l}\text { Is waste ready for } \\
\text { transfer? }\end{array}$} & Slurry Density & $\begin{array}{l}\text { Slurry density must } \\
\text { be low enough to } \\
\text { prevent solids } \\
\text { settling in the pipe. }\end{array}$ \\
\hline & & Viscosity & $\begin{array}{l}\text { Viscosity must be low } \\
\text { enough to assure pump } \\
\text { will provide } \\
\text { sufficient flow. }\end{array}$ \\
\hline & & Temperature & $\begin{array}{l}\text { 1. Temperature of } \\
\text { slurries must be } \\
\text { within the design } \\
\text { range. } \\
\text { 2. STurry temperature } \\
\text { must exceed lower } \\
\text { pumpability limit } \\
\text { (see Compatibility } \\
\text { DQ0, Fowler 1995). }\end{array}$ \\
\hline & & Volume percent solids & $\begin{array}{l}\text { Percent solids must } \\
\text { be low enough to } \\
\text { prevent settling in } \\
\text { the pipe. }\end{array}$ \\
\hline & $\begin{array}{l}\text { Is waste compatible } \\
\text { for transfer? }\end{array}$ & $\begin{array}{l}\text { Covered in } \\
\text { Compatibility DQ0 } \\
\text { (Fowler 1995), under } \\
\text { mixing of "Tank Waste } \\
\text { Type" } \\
\text { See Section } 4.2 .2 \\
\end{array}$ & \\
\hline 3 & $\begin{array}{l}\text { Is waste sufficiently } \\
\text { removed? }\end{array}$ & See Section 4.2 .3 & \\
\hline
\end{tabular}


Table 4-1 (cont). Summary of SST and DST Retrieval Input Decisions.

\begin{tabular}{|c|c|c|c|}
\hline $\begin{array}{l}\text { Dec. } \\
\text { No. }\end{array}$ & Decision & Decision Inputs & $\begin{array}{l}\text { Reason for Requesting } \\
\text { Decision Inputs }\end{array}$ \\
\hline 4 & $\begin{array}{l}\text { Which alternate } \\
\text { retrieval method is } \\
\text { required to remove } \\
\text { the waste? }\end{array}$ & $\begin{array}{l}\text { Will be defined as } \\
\text { project matures. } \\
\text { See Section } 4.2 .4\end{array}$ & \\
\hline 5 & $\begin{array}{l}\text { Is DST retrieval } \\
\text { system equipment } \\
\text { adequate for the } \\
\text { waste to be } \\
\text { retrieved? }\end{array}$ & See Section 4.2 .5 & \\
\hline \multirow[t]{3}{*}{6} & \multirow[t]{3}{*}{$\begin{array}{l}\text { Is mobilized sludge } \\
\text { volume predicted by } \\
\text { ECR equation? }\end{array}$} & Shear strength & $\begin{array}{l}\text { Settled sludge } \\
\text { removal is dependent } \\
\text { on shear strength } \\
\text { (based on the current } \\
\text { ECR equation). }\end{array}$ \\
\hline & & S7udge profile & $\begin{array}{l}\text { Sludge profile will } \\
\text { be used to verify the } \\
\text { ECR equation. }\end{array}$ \\
\hline & & Slurry density & $\begin{array}{l}\text { Determination of } \\
\text { suspended slurry is } \\
\text { an indication of } \\
\text { settled sludge } \\
\text { mobilized. }\end{array}$ \\
\hline \multirow[t]{2}{*}{7} & $\begin{array}{l}\text { Is waste ready for } \\
\text { transfer? }\end{array}$ & See Decision 2 & \\
\hline & $\begin{array}{l}\text { Is waste compatible } \\
\text { for transfer? }\end{array}$ & & \\
\hline 8 & $\begin{array}{l}\text { Are mobilized waste } \\
\text { parameters within } \\
\text { cross site transfer } \\
\text { design limits? }\end{array}$ & See Section 4.2 .6 & \\
\hline 9 & $\begin{array}{l}\text { Are mobilized waste } \\
\text { acceptable for } \\
\text { pretreatment feed? }\end{array}$ & See Section 4.2 .7 & \\
\hline
\end{tabular}

\subsubsection{Decision 9 - Pretreatment Requirement}

Pretreatment requirements for acceptable waste as pretreatment feed will be determined as part of the store waste function and is included in the scope of the Pretreatment $D Q 0$. Transfer waste must meet pretreatment requirements before transferring. 


\section{WHC-SD-WM-DQ0-008 REV 1}

\subsection{DECISION RULE}

\subsection{SUMMARY OF DECISION RULE}

Selected decisions with defined characterization data from Figures 3-1 and 3-2 are shown, in a tabular form in Table 5-1. Only decisions with resolved issues will be addressed in this table. The first column from the left shows the decision number, the second column restates the decision question, the third column presents the decision threshold, and the fourth column indicates the action needed depending on the satisfactory condition of current input. The generic statement for the logic decision shown below is as follows:

Decision Number: IF condition THEN action.

It is recognized that some decisions may require several input conditions to proceed. The generat statement for this is as follows:

Decision Number: IF (condition I and condition2 and ...) THEN action.

\subsection{JUSTIFICATION OF DECISION THRESHOLD}

This section provides the justification for Decisions 2,6 , and 7 . The justification provides a technical basis for the assigned threshold value. Table 5-2 summarizes the result. 
Table 5-1. Decision Rules for Retrieval Operation

\begin{tabular}{|c|c|c|c|}
\hline $\begin{array}{l}\text { Dec } \\
\#\end{array}$ & $\begin{array}{l}\text { Decision } \\
\text { Description }\end{array}$ & IF (decision threshold) & THEN \\
\hline \multirow[t]{3}{*}{2} & \multirow[t]{3}{*}{$\begin{array}{l}\text { Is waste ready } \\
\text { for transfer? }\end{array}$} & $\begin{array}{l}\text { Calculated Reynolds } \\
\text { number } \geq 20,000 \text { (dilute } \\
\text { waste to meet } \\
\text { requirement) } \\
\text { Note: Reynolds number is } \\
\text { calculated from specific } \\
\text { gravity (slurry } \\
\text { density), velocity and } \\
\text { viscosity. } \\
\text { Thresholds imposed on } \\
\text { slurry density and } \\
\text { viscosity are also } \\
\text { defined by the design of } \\
\text { the convey system. }\end{array}$ & \multirow[t]{3}{*}{ Proceed to transfer. } \\
\hline & & $\begin{array}{l}\text { Temperature > saturation } \\
\text { temperature of waste }\end{array}$ & \\
\hline & & $\begin{array}{l}\text { Volume Percent } \\
\text { Solids }<30 \text { vol\% }\end{array}$ & \\
\hline 6 & $\begin{array}{l}\text { Is mobilized } \\
\text { sludge volume } \\
\text { predicted by } \\
\text { ECR equation? }\end{array}$ & $\begin{array}{l}\text { Proposed ECR equation } \\
\text { predicts mobilized } \\
\text { volume within actual } \\
\text { volume } \pm 20 \% \text { for } W-151 \\
\text { tank } A Z-101\end{array}$ & $\begin{array}{l}\text { Determine number of mixer } \\
\text { pumps required by using } \\
\text { ECR equation to predict } \\
\text { percent waste mobilized } \\
\text { for each pump. }\end{array}$ \\
\hline \multirow[t]{4}{*}{7} & \multirow[t]{4}{*}{$\begin{array}{l}\text { Is waste ready } \\
\text { for transfer? }\end{array}$} & Slurry Density & \multirow{4}{*}{$\begin{array}{l}\text { The threshold requirements } \\
\text { for these parameters are } \\
\text { similar to decision number } \\
2 \text { above except that } \\
\text { additional restriction for } \\
\text { these properties can be. } \\
\text { imposed by either the } \\
\text { cross site transfer } \\
\text { requirements or } \\
\text { pretreatment requirements. }\end{array}$} \\
\hline & & Viscosity & \\
\hline & & Temperature & \\
\hline & & Volume Percent Solids & \\
\hline
\end{tabular}


Table 5-2. Justification of Decision Threshold

\begin{tabular}{|c|c|c|}
\hline $\begin{array}{l}\text { Decision } \\
\text { Number }\end{array}$ & Decision Threshold & Justification \\
\hline \multirow[t]{3}{*}{2} & $\begin{array}{l}\text { Reynolds number } \\
\geq 20,000\end{array}$ & $\begin{array}{l}\text { Reynolds number determines the } \\
\text { pumpability of the waste. Data needs for } \\
\text { calculating the Reynolds number are waste } \\
\text { density, viscosity, pipe diameter and } \\
\text { pump velocity (Fowler 1995). }\end{array}$ \\
\hline & $\begin{array}{l}\text { Temperature > waste } \\
\text { saturation } \\
\text { temperature }\end{array}$ & $\begin{array}{l}\text { Transfer temperature must be above the } \\
\text { saturation temperature of the waste so } \\
\text { that no precipitation or gelation will } \\
\text { occur during transfer. Additional } \\
\text { constraints from the convey system may } \\
\text { supersede this requirement (Fowler 1995). }\end{array}$ \\
\hline & $\begin{array}{l}\text { Volume Percent Solids } \\
<30 \text { vol\% }\end{array}$ & $\begin{array}{l}\text { The } 30 \text { vol\% is the design parameter for } \\
\text { the cross site transport } 1 \text { ine. Without } \\
\text { proper dilution, waste can settle and } \\
\text { plug pipes (Kalia 1994). The } 30 \text { vol\% is } \\
\text { also a decision threshold for the waste } \\
\text { probability rule (Fowler 1995). The } 30 \\
\text { vol\% limit is undergoing review at this } \\
\text { time. }\end{array}$ \\
\hline 6 & $\begin{array}{l}\text { Predicted mobilized } \\
\text { volume percent is } \\
\text { within actual volume } \\
\pm 20 \%\end{array}$ & $\begin{array}{l}\text { The actual mobilized volume percent must } \\
\text { be within } \pm 20 \% \text { of the predicted amount } \\
\text { in order to select the correct ECR } \\
\text { correlation. }\end{array}$ \\
\hline 7 & Same as Decision 2 & $\begin{array}{l}\text { Additional constraints may be applied } \\
\text { either from the cross site transfer } \\
\text { system or the pretreatment project. }\end{array}$ \\
\hline
\end{tabular}




\subsection{ACCEPTABLE CONFIDENCE LIMITS FOR DECISION INPUTS}

\subsection{PHYSICAL BOUNDARIES OF DECISION INPUTS}

Physical boundaries of decision inputs are defined and justified in Table $6-1$. These boundaries indicate the area where tank waste data are needed. Most physical boundaries for measurement, as indicated in Table 6-1, are in-place or in-tank measurement. Data are needed during operation (in recirculation loop) or verification of a design (ECR of mixer pump). If demonstrated measurement sensors were unavailable, core sample data could provide useful information on tank waste shear strength and grab samples could be used for slurry density. Sludge profile could be measured by direct measurement but with much less certainty and very infrequently.

Table 6-1. Physical Boundaries for Decision Inputs

\begin{tabular}{|c|c|c|c|}
\hline $\begin{array}{l}\text { Dec } \\
\# \\
\end{array}$ & $\begin{array}{l}\text { Decision } \\
\text { Input }\end{array}$ & Physical Boundary & Justification \\
\hline \multirow[t]{4}{*}{2} & $\begin{array}{l}\text { Slurry } \\
\text { Density }\end{array}$ & \multirow{4}{*}{$\begin{array}{l}\text { Within } 3 \text {-inch piping } \\
\text { of the recirculation } \\
\text { loop. }\end{array}$} & \multirow{2}{*}{$\begin{array}{l}\text { To simulate actual waste } \\
\text { transfer environment, flow } \\
\text { turbulence must be measured } \\
\text { in a region similar to } \\
\text { transfer piping. }\end{array}$} \\
\hline & Viscosity & & \\
\hline & Temperature & & $\begin{array}{l}\text { Changes in temperature as } \\
\text { waste moves through the } \\
\text { transfer piping can be } \\
\text { simulated using the } \\
\text { recirculation loop. }\end{array}$ \\
\hline & $\begin{array}{l}\text { Volume } \\
\text { Percent } \\
\text { Solids } \\
\end{array}$ & & $\begin{array}{l}\text { To simulate actual waste } \\
\text { transfer environment. }\end{array}$ \\
\hline \multirow[t]{3}{*}{6} & $\begin{array}{l}\text { Shear } \\
\text { Strength }\end{array}$ & $\begin{array}{l}\text { In-tank: Within the } \\
\text { settled sludge layer }\end{array}$ & $\begin{array}{l}\text { ECR equation requires shear } \\
\text { strength of sludge to be } \\
\text { mobilized. }\end{array}$ \\
\hline & $\begin{array}{l}\text { Sludge } \\
\text { Profile }\end{array}$ & $\begin{array}{l}\text { In-tank: Measure } \\
\text { sludge layer at the } \\
\text { bottom of tank. }\end{array}$ & $\begin{array}{l}\text { Change in sludge layer gives } \\
\text { measure of sludge volume } \\
\text { mobilized. }\end{array}$ \\
\hline & $\begin{array}{l}\text { Slurry } \\
\text { Density }\end{array}$ & $\begin{array}{l}\text { In-tank: Measure } \\
\text { within waste tank } \\
\text { slurry layer. }\end{array}$ & $\begin{array}{l}\text { Change of in-tank slurry } \\
\text { density is a measure of } \\
\text { amount of sludge volume } \\
\text { mobilized. }\end{array}$ \\
\hline 7 & $\begin{array}{l}\text { Same as } \\
\text { Decision } 2\end{array}$ & & \\
\hline
\end{tabular}




\subsection{DECISION INPUT CONFIDENCE LIMITS}

The decision thresholds are summarized in Section 5.1. Since the decision threshold numbers determine what path the logic flow will proceed in the DQO, it is desired to know what confidence is required in determining if the decision input meets the threshold. Table 6-2 provides the desired confidence interval for the decision input threshold limits. The confidence interval requirements and basis for the Reynolds number, saturation temperature, and percent solids input threshold limits are provided (Fowler 1995).

Instrumentations for the mixer pump demonstration test is required to measure/determine ECR, discharge velocity times nozzle diameter (U.D), and sludge shear strength accurately enough to identify a preferred Pacific Northwest Laboratory (PNL) model for predicting ECR or to reject both PNL mode1s.

Preliminary results of the analysis indicate a $90 \%$ confidence interval is adequate for Decision 6 which determines which PNL equation to use for predicting ECR. Professionals familiar with the operation, waste types, and instruments will determine the required measurement error tolerance to meet the confidence interval requirements as part of the sampling optimization step of this retrieval DQO process yet to be completed.

Table 6-2. Tolerance Requirement for Decision Inputs

\begin{tabular}{|c|c|c|}
\hline $\begin{array}{l}\text { Dec. } \\
\text { Number }\end{array}$ & Decision Threshold & Confidence \\
\hline \multirow[t]{3}{*}{2} & Reynolds number $\geq 20,000$ & \multirow[t]{3}{*}{ (Fowler 1995) } \\
\hline & $\begin{array}{l}\text { Temperature > waste } \\
\text { saturation temperature }\end{array}$ & \\
\hline & $\begin{array}{l}\text { Volume Percent Solids }<30 \\
\text { vol\% }\end{array}$ & \\
\hline 6 & $\begin{array}{l}\text { Predicted mobilized volume } \\
\text { within } \pm 20 \% \text { of actual } \\
\text { mobilized volume. }\end{array}$ & $90 \%$ \\
\hline 7 & See Decision 2 & \\
\hline
\end{tabular}




\subsection{DECISION INPUT SOURCES}

Measurement methods or sources that can be used to obtain tank waste data to support the retrieval operation are indicated in Table 7-1. Sources indicated in the table are the possible technologies that can be used, and the most desirable method is listed in order with 1 being the most desirable. For instance, shear strength can be measured in a laboratory or in a waste core sample, using the in situ shear vane or cone penetrometer, but the shear vane method is most preferable.

The possible decision input sources shown in Table 7-1 were based on existing technologies available at the Hanford Site. The decision to use a selected source is based on making the measurement for each tank. Additional methods may be used after successful testing and verification.

Table 7-1. Decision Input Sources

\begin{tabular}{|c|c|c|}
\hline $\begin{array}{l}\text { Decision } \\
\text { No. }\end{array}$ & Decision Input & Possible Decision Input Sources \\
\hline \multirow[t]{4}{*}{2} & Slurry Density & $\begin{array}{l}\text { 1. In situ mass/flow density meter (in } \\
\text { pipe) } \\
\text { 2. In situ ultrasonic sensor (in pipe) } \\
\text { 3. Grab sample }\end{array}$ \\
\hline & Viscosity & $\begin{array}{l}\text { 1. In situ viscometer (in pipe) } \\
\text { 2. Grab sample }\end{array}$ \\
\hline & Temperature & Thermocouple \\
\hline & $\begin{array}{l}\text { Volume Percent } \\
\text { Solids }\end{array}$ & $\begin{array}{l}\text { 1. Grab sample } \\
\text { 2. In situ sensor (in pipe) }\end{array}$ \\
\hline \multirow[t]{3}{*}{6} & Shear Strength & $\begin{array}{l}\text { 1. In situ shear vane } \\
\text { 2. Cone penetrometer } \\
\text { 3. Core sample }\end{array}$ \\
\hline & Sludge Profile & $\begin{array}{l}\text { 1. In situ ultrasonic sensor } \\
\text { 2. Gamma sensor } \\
\text { 3. Temperature profile from } \\
\text { thermocouple tree } \\
\text { 4. Manual profile measurement }\end{array}$ \\
\hline & Slurry Density & $\begin{array}{l}\text { In situ turbidity sensor and } \\
\text { grab sample }\end{array}$ \\
\hline 7 & Same as Decision 2 & \\
\hline
\end{tabular}




\subsection{BOUNDING TANKS}

Characterization of actual tank waste is expensive and minimization of sampling requirements is an important method for reducing program costs. Methods used to reduce retrieval sampling requirements include utilizing historical data, using in situ instrumentation, minimizing the number of tanks that will be characterized or sampled, using the least expensive sampling method, and requesting only necessary analysis while obtaining adequate waste information for the identified decisions.

Retrieval tank waste characterization requirements will be addressed in two phases to meet the intent of obtaining adequate waste information for the least cost. The retrieval function and decisions included in Phase 1 and those included in Phase 2 are indicated in Figures 3.1 and 3.2 for SST and DST projects, respectively. The first phase of waste characterization for retrieval is addressed by this retrieval DQO and are the needs identified at this time. The first phase of tank waste characterization will utilize historical data, development of in situ instrumentation, and use of data obtained for other programs to provide the necessary waste data.

Some slurry grab samples are required to caljbrate in situ instruments during the mixer pump demonstration test of Project W-151. No other new tank waste samples are requested for retrieval design, development, and operations in the current Phase 1 . Waste information required for retrieval system design and operation will be obtained from historical records, in situ instrumentation, documentation of operational experiences, and data obtained for other programs, such as requirements for pretreatment or safety programs.

It is recognized that retrieval systems design and operations considerations may cause additional safety-related questions concerning criticality, release of noxious gases, flammable gas accumulation, or others. Permitting and equipment disposal are additional considerations which may require waste information during design of retrieval projects. Waste samples and analysis may be required in the future to provide information to resolve specific issues arising in these areas.

Reevaluation of retrieval information needs will be required during the design of the retrieval systems to determine if safety or operational requirements require additional data. The second phase of tank waste characterization occurs after reevaluation and it is determined that specific high-impact information requirements exist, a carefut assessment of the available data is completed, and additional waste information is found necessary. If necessary, a revised retrieval DQO would be prepared during Phase 2.

\subsection{BOUNDING TANKS FOR SST DATA}

During Phase 1 no new tank waste samples are requested for SST retrieval design, development, and operations. Historical data and documentation of operating experience in installation of saltwell pumps and thermocouple trees in saltcake waste will be used to implement past-practice sluicing equipment design selection. 
Tank waste data requirements for the initial sluicing demonstration in tank 241-C-106 are addressed in the 241-C-106 DQ0. Therefore, they are not addressed in this retrieval DQO. Safety and operations compatibility were evaluated and the results documented (Sederburg 1994).

Currently proposed SSTs to be retrieved by the ISSTRS are 241-A-102, 241-AX-103, 241-C-103, and 241-C-105. Other tanks in the $A, A X, C, T X, B Y$, and $S$ farms are also being considered for retrieval and are assigned second priority. Historical tank waste data from all SSTs is desired but tanks in farms $A, A X$, and $C$ are given high priority since they are being considered for the ISSTRS project.

\subsection{BOUNDING TANKS FOR DST DATA}

During Phase 1 only a few tank waste slurry grab samples from 241-AZ-101 during the mixer pump process test are required for DSTs retrieval design. Preliminary waste information requirements identified for DST retrieval, Appendix $B$, will initially be addressed without new waste sampling specifically for retrieval. New waste samples may be required if specific data requirements are identified in Phase 2.

Characterization data obtained for the tank safety and pretreatment programs and historical data will be utilized to satisfy information needs required for retrieval system design during Phase 1 . Once the source and receiver tanks are identified for the initial retrieval project, available data will be assessed to meet information needs, including the criteria of the Compatibility DQQ (Fowler 1995).

Operational tank waste data information requirements for the pumpability decision concerning waste transfers and the design information requirements for determining the number of mixer pumps for DSTs could be provided with in situ instruments which are currently proposed for development or demonstration. No waste sampling will be necessary if the identified in situ instruments are successfully demonstrated. Grab sampling of the mobilized waste in the waste recirculation lines during retrieval operations may continue to provide waste samples for limited analys is to assure the waste meets pumpability requirements if the in situ sensors are not developed.

Current1y, tanks 241-SY-102 and 241-AW-105 are considered the highest priority DSTs. Eventually, all DSTs wi1l be retrieved and tank waste information required. Available compatibility information will be collected for these tanks from historical records tank characterization reports and data obtained for other programs.

The tank retrieval sequence is currentiy in development and the previous retrieval sequence for the initial retrieval of DSTs is being revised. Additional changes in the sequence are likely and historical data and data from other programs are adequate until a retrieval sequence is determined. Once the tanks to be retrieved are identified and confirmed, new data requirements will be determined after historical data is assessed. 
The hazards analysis, preliminary safety evaluation, and safety assessment for initial retrieval of the DSTs are based on historical data. Specific detailed retrieval system design for each DST to be retrieved will also be based on historical data when it is sufficient. Retrieval system equipment safety class requirements are determined in the safety assessment.

Safety and operations compatibility must be assured prior to waste transfer operations and any sampling requirements for operations will be identified once the tanks to be retrieved are determined.

\subsection{IMPACT OF RETRIEVAL DECISIONS}

The impact on cost and schedule of the retrieval process, when tank waste information is not available or incorrectly measured, is addressed in this section. The decision inputs considered are waste conditioning for transport and confirmation of mobilized volume after mixer pump completion. Table 9-1 lists decision inputs and the associated impact of wrong decisions. Justifications for the estimated costs and schedules indicated in the table are shown in Appendix C.

Table 9-1. Impact of Retrieval Decisions

\begin{tabular}{|c|c|c|c|c|}
\hline $\begin{array}{l}\text { Dec. } \\
\#\end{array}$ & Decision Description & $\begin{array}{l}\text { Impact of Wrong } \\
\text { Decision }\end{array}$ & Bounding Cost & $\begin{array}{l}\text { Delay } \\
\text { (months) }\end{array}$ \\
\hline \multirow[t]{3}{*}{2} & \multirow[t]{3}{*}{$\begin{array}{l}\text { Is waste ready for } \\
\text { transfer? }\end{array}$} & \multirow{3}{*}{$\begin{array}{l}\text { Plug pipes, } \\
\text { sections of } \\
\text { pipes or } \\
\text { diversion boxes. }\end{array}$} & $\begin{array}{l}\$ 47 M / \text { cross site } \\
\text { transfer sys. }\end{array}$ & 50 \\
\hline & & & $\$ 515 \mathrm{~K} / 20-\mathrm{ft}$ pipe & 4 \\
\hline & & & $\$ 160 \mathrm{~K} / \mathrm{div}$. box & $2-5$ \\
\hline 6 & $\begin{array}{l}\text { Is mobilized sludge } \\
\text { volume predictable } \\
\text { by ECR equation? }\end{array}$ & $\begin{array}{l}\text { This is a } \\
\text { potential cost } \\
\text { saving, but } \\
\text { could cause a } \\
\text { cost and } \\
\text { performance } \\
\text { penalty. }\end{array}$ & $\begin{array}{l}\text { Save } \$ 7.5 \mathrm{M} \text { per } \\
\text { pump }\end{array}$ & \\
\hline 7 & $\begin{array}{l}\text { Is waste ready for } \\
\text { transfer? }\end{array}$ & See Decision 2 & & \\
\hline
\end{tabular}

For Decision 2 the most probable impact of a line starting to plug during transfer operations is simply that a line flush would be required. Typical recovery is to flush, which is normally successful. If not flushed successfully, the less likely event would be line plugging and that a section of transfer pipe would have to be replaced. The least likely event would be replacement of the entire line at a cost of $\$ 47 M$. 
Decision 6 involves providing a basis for determination whether one mixer pump is sufficient to remove sludge waste in a DST. The reference retrieval system for DSTs is two mixer pumps. If tank waste shear strength is not known, two referenced mixer pumps will be used. This decision is a potential cost saving decision; however, there is also a potential cost penalty for making a wrong decision in selecting one mixer pump. The cost savings in using one mixer pump includes design, fabrication, installation, and maintenance costs that approaches $\$ 7.5 \mathrm{M}$. A wrong decision would require installation of the second mixer pump that will delay the retrieval schedule and reduce mixer pump system performance. Mixer pump system performance would be reduced by geometry effects since the two mixer pumps would not be in the optimum positions for maximum mobilization.

\subsection{DATA PRIORITY}

The relative priority of the waste characterization data is indicated in this section. The highest priority information is described first and the lower priority information is described in descending order of priority. As information needs are clearly defined and justified, it is likely that this order will change.

Safety and operations data requirements from the Tank Farms Compatibility Program and corresponding Compatibility DQO apply to waste transfers planned for the retrieval projects. The potential for triggering the release of accumulated gases (hydrogen, nitrous oxide, ammonia), criticality, and other identified safety concerns due to transfer operations is evaluated in the safety analys is for each retrieval project.

Information is required to assure pumpability and prevent plugging of transfer lines during transfer operations. Measurement of slurry flowrate, density, and viscosity are required to determine the Reynolds number and demonstrate that turbulent flow will occur in the transfer pipe. The Reynolds number of the flowing slurry must be above 20,000 during the transfer operation to meet the compatibility pumpability criteria.

Percent solids measurement is currently required in the compatibility criteria. Development test activities planned for determining a method for assuring pumpability may demonstrate that percent solids measurement or Reynolds prediction may be replaced by other measurements which predict or monitor the transfer operation adequately. Proposed development of in situ sensors may provide methods which would replace physical property measurements on grab samples.

Information is required to determine if one mixer pump is adequate for mobilization of a DST. In situ measurement of shear strength, sludge surface profile, and slurry density during the mixer pump demonstration Project $W-151$ is required to confirm the ECR equation has the potential of providing the basis for eliminating one of the two referenced mixer pumps and associated cost for several of the DSTs to be retrieved by the DST retrieval Project $W-211$. 
Physical properties are proposed as a basis for selection of alternate retrieval equipment. The relatively lower priority is assigned since the alternate equipment will not be selected until after sluicing is complete and no specific high-impact project decisions have been identified. future identification of specific decisions of high impact to the project may raise the priority and will be assessed after waste removal from the first SST farm is complete. A consideration of some of the proposed processes and tank waste physical properties desired to develop the retrieval equipment is given in Appendix A.

Sampling of waste, for the preliminary information requirements identified for Project $W-211$ in Appendix $B$, is not justified unt $i 1$ the retrieval sequence is finalized and specific data requirements are identified. Tank waste data obtained for other programs and historical data will be utilized in the meantime to meet these requirements. The retrieval $D Q O$ Phase 2 will identify and justify specific sampling requests. If samples are taken from DSTs that contain solids in the interim, the retrieval data needs identified in Appendix $B$ should be assessed for applicability by the characterization effort.

\subsection{REFERENCES}

Agnew, S. F., 1994, Tank Layer Model (TLM), for Northeast, Southwest, and Northwest Quadrants, LA-UR-94-4269, Rev 1, Los Alamos National Laboratories, Los Alamos, New Mexico.

Brevick, C. H., 1995a, Historical Tank Content Estimate for the Northeast Quadrant of the Hanford 200 East Areas, WHC-SD-WM-ER-349, Rev. 2, Westinghouse Hanford Company, Richland, Washington.

Brevick, C. H., 1995b, Historical Tank Content Estimate for the Northwest Quadrant of the Hanford 200 East Areas, WHC-SD-WM-ER-351, Rev. 0, Westinghouse Hanford Company, Richland, Washington.

Brevick, C. H., 1995c, Historical Tank Content Estimate for the Southwest Quadrant of the Hanford 200 East Areas, WHC-SD-WM-ER-352, Rev. 2, Westinghouse Hanford Company, Richland, Washington.

DOE/RL, 1994, Tank Waste Remediation Systems (TWRS) Functions and Requirements, DOE/RL 92-60, Rev. 1, U.S. Department of Energy, Richland Field office, Richland, Washington.

Fowler, K. D., 1995, Data Quality Objectives for Tank Farms Waste Compatibility Program, WHC-SD-WM-DQO-001, Rev. 1, Westinghouse Hanford Company, Richland, Washington.

Gates, C. M., and M. R. Beckette, 1995, Identification of Physical Properties for the Retrieval Data Quality Objective Process, PNL-10637, Pacific Northwest Laboratory, Richland, Washington. 
Johnson, G. D. 1995, Flammab7e Gas Tank Safety Program: Data Requirements for Core Sample analysis Developed Through the Data Quality Objectives Process, WHC-SD-WM-DQ0-004 REV 1, Westinghouse Hanford Company, Richland, Washington.

Kalia, J., 1994, Replacement of Cross Site Transfer System, WHC-SD-W058-FDC001 , Rev. I, Westinghouse Hanford Company, Richland, Washington.

Kelley, T. J., 1994, Letter, T. J. Kelley (WHC) to J. M. Clark (RL), Examp7e Data Quality Objectives Document, 9558470, Westinghouse Hanford Company, Richland, Washington.

Kidder, R. J., 1994, Preliminary Safety Evaluation for the Initial Tank Retrieval Systems, Project W-211, WHC-SD-W211-PSE-002, Rev. 0 , Westinghouse Hanford Company, Richland, Washington.

Kohlman, E. H., 1993, Tank 101-AZ Waste Retrieval System, WHC-SD-W151-FDC-001 REV 3, Westinghouse Hanford Company, Richland, Washington.

Krieg, S. A., W. W. Jenkins, K. J. Leist, K. E. Squires, and J. F. Thompson, 1990, Single-Shell Tank Waste Retrieval Study, WHC-EP-0352, Westinghouse Hanford Company, Richland, Washington.

Kupfer, M. J., 1995, Data Needs and Attendant Data Quality Objectives for Tank Waste Pretreatment and Disposal, WHC-SD-WM-DQO-022 REV 0 , Westinghouse Hanford Company, Richland, Washington.

Powe11, M. R., C. M. Gates, M. A. Sprecher, and N. J. Morter, 1994, Fiscal Year 1994 1/25th Scale Sludge Mobilization Testing, PNL-10482, Pacific Northwest Laboratory, Richland, Washington.

Rieck, C. A., 1995, Functional Design Criteria, Project W-211, Initial Tank Retrieval Systems, WHC-SD-W211-FDC-001 REV 1, Westinghouse Hanford Company, Richland, Washington.

Rodenhizer, D. G., 1987, Hanford Waste Tank Sluicing History, WHC-SD-WM-TI-302, Westinghouse Hanford Company, Richland, Washington.

Sederburg, J. P., 1994, Chemical Compatibility of Tank Wastes in Tanks 241-C$106,241-A Y-101$, and 241-AY-102, WHC-SD-WM-ES-290 REV 2, Westinghouse Hanford Company, Richland, Washington.

Summers, 1993, Waterjetting Technology, University of Missouri-Rolla, Rolla, Missouri.

Summers, D. A., R. D. Fossey, M. D. Mann, and V. G. Blaine, 1994, Hazardous Waste Dislodging and Conveyance: The Confined Sluicing Method, PNL-10074, Pacific Northwest Laboratory, Richland, Washington. 


\section{APPENDIX A: MOBILIZATION TECHNOLOGY DESCRIPTIONS}

Appendix A describes the mobilization technologies for SST and DST, sluicing system and mixer pump system, respectively. Alternate mobilization equipment will be used for removing material left by the reference systems, if required. Secondary decision inputs and parameters needed for the aiternate retrieval systems are shown in Tables A-1 through A-3. The decision information is used to identify information required design or development of the alternate retrieval methods.

\section{Past-Practice Sluicing System}

The reference approach for mobilization and retrieval of SST waste is past-practice sluicing. This method, uses high volume (i.e., $300 \mathrm{gpm}$ ), high pressure waterjets to mobilize the solids, and a slurry pump to convey the resulting liquid/solid slurry.

The sluicing system (Figure A-1) consists of a sluicer, a vertical pump for slurry removal and mixing, and a visual monitoring system. The sluicer, with a rotating nozzle, can direct the waterstream to the location of waste needing mobilization. The waste is dislodged by waterjet impact, some soluble waste may be dissolved, and waste particles are suspended in a slurry and washed into an area of the tank where the slurry is pumped to the surface. flowrate between 250 and $300 \mathrm{gpm}$ was used through each $1-3 / 8$ inch sluicing nozzle with a supply pressure of $100 \mathrm{psi}$. The slurry can be removed hydraulically (pumping) or pneumatically (air conveyance). Sluicing is an old practice (used over a hundred years ago in placer mining) and was used extensively in retrieval operations in the past at the Hanford Site. The past-practice sluicing equipment design used at the Hanford Site during the T-plant and B-plant processing campaign (Rodenhizer 1987) will be utilized in the retrieval of tank 241-C-106 and the ISSTRS.

To identify the waste properties important to sluicing technology, a mathematical model (Summer 1994 and Gates, et al. 1995) was proposed that shows the relationship between the retrieval rate to the nozzle size and various tank waste properties (such as shear strength, particle size distribution, salt dissolution, and porosity). This model was developed based on the sluicing of sludge waste data, but it was proposed that it could be extended to include saltcake waste. The model is being developed and has not been verified. However, since we are not using the model to make any decisions, its further development and/or verification are not required. 


\section{WHC-SD-WH-DQO-008 REV 1}

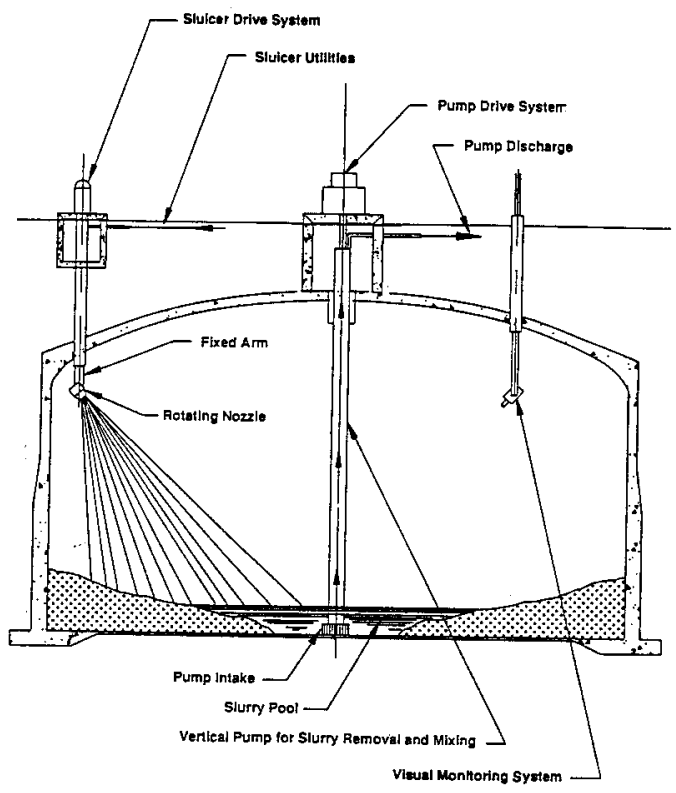

Figure A-1. SST Sluicing Operating Scenario 


\section{Mixer Pump System}

The reference approach for mobilization of DST waste is the mixer pump. The mixer pump will mobilize the settled sludge into the supernate, creating a slurry suitable for transfer by a separate transfer pump. A typical single mixer pump installation in a DST is shown schematically in Figure A-2.

\section{Double-Shell Tank Retrieval System}

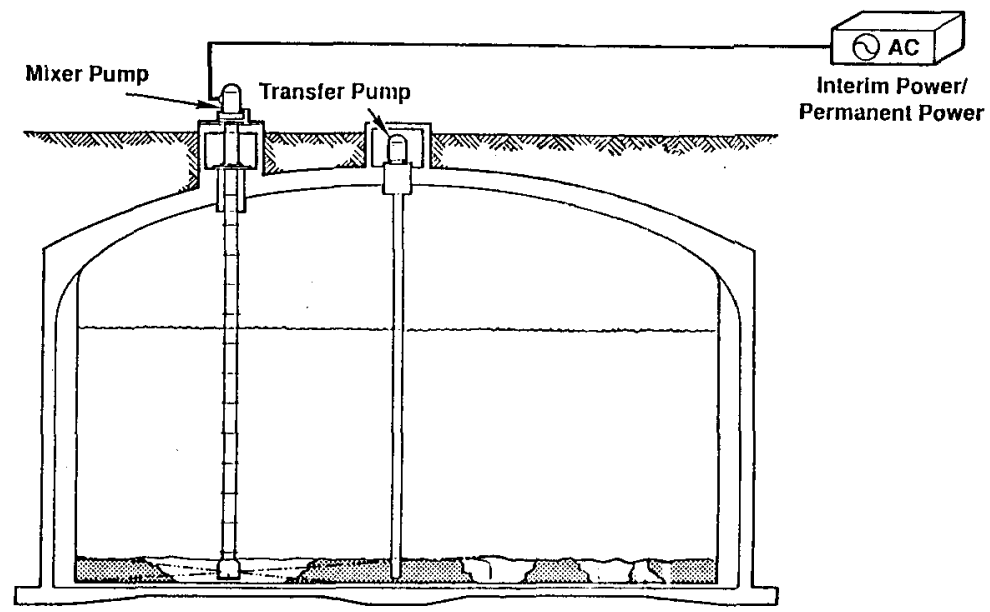

Figure A-2. Mixer Pump Installation in a DST

Each mixer pump takes in slurry from the bottom of the tank and discharges the fluid horizontally through two opposing nozzles. Simultaneously, the nozzle assembly oscillates approximately 180 degrees at a low rate (i.e., $0.2 \mathrm{rpm}$ ), sweeping the jet past the sludge and mobilizing more of the sludge with each pass. Additional supernate (or diluent) may be added to some tanks to achieve the desired slurry concentration. 
Mixer pump(s) will be made of stainless steel to provide prolonged pump 1 ife and to facilitate mixer pump cleaning and disposal. Current knowledge of radiation dose rates for different waste types will be utilized in material selection for mixer pumps. Seals and bearings will be constructed of the best available material to withstand slurry. At present, development of improved pump seals is an ongoing effort among Westinghouse Hanford Company, West Valley, and Savannah River. Bearing design for pumps is based on present knowledge of the existing tank waste data, best mechanical design, and best available materials.

Capacity of the mixer pump can be stated in terms of nozzle diameter, nozzle discharge velocity of the pump, and specific tank waste properties. The current TWRS plan is to purchase the highest capacity pumps that will fit into existing 34 inch or 42 inch risers. The distance from a jet nozzle of the mixer pump to the most distant sludge that it can mobilize is the key measure of mixing pump performance and is referred to as the ECR (Powell et al. 1994) and (Gates and Beckette 1995). The current methodology utilizes sludge shear strength and jet parameters to predict ECR. Extensive tests have been completed to validate the ECR model. Correlations were developed by using various mixtures of simulants (bentonite and kaolin) in $1 / 25$ th and 1/12th scale tests. Estimated ECR equations are as follows:

$$
\begin{aligned}
& \frac{E C R}{U_{0} D}=17.3 \tau^{-0.67} \\
& \frac{E C R}{V_{0} D}=2.3 \tau^{-0.41}
\end{aligned}
$$

where $U_{0}$ is the nozzle water velocity $(\mathrm{cm} / \mathrm{s})$, D is the nozzle diameter $(\mathrm{cm})$, $r$ is the cohesive portion of the shear strength (dynes $/ \mathrm{cm}^{2}$ ), and ECR is in centimeters (Gates et a1., 1995). The first ECR equation is valid for low range of shear strength $\left(10,000\right.$ to 15,000 dynes $\left./ \mathrm{cm}^{2}\right)$. The second $E C R$ equation is recently developed for a wider range of shear strength.

\section{Enhanced or Alternate Systems}

Enhanced or alternate mobilization systems will be considered if pastpractice sluicing fails to remove tank waste sludge to an acceptance criteria. Enhancements to sluicing inciude higher pressure, nozzle size and shape, and pump alterations that would result in less standing water. Potential a)ternate systems (Krieg et al. 1990) are scarifier, confined sluicing, and new systems which will be identified through the ACTR program. The scarifier can utilize high-pressure air jets or steam jets to dislodge small pieces of waste. Alternate conveyance methods include pneumatic and combined pneumatic/waterjet pump conveyance. Descriptions of these systems are given in the following sections. Additional technologies are also being evaluated to provide other mobilization and conveyance options. 


\section{WHC-SD-WM-DQO-008 REV 1}

Tank waste data are needed to select these alternate systems and the properties of interest are described below. The third priority alternate retrieval system design decisions identified in this DQO process does not justify the high cost of new core sampling and analysis. Historical data and data obtained for other programs will be utilized by the ACTR program until specific project decisions having high impact are identified.

\section{A. Pneumatic Conveyance}

Pneumatic (or air) conveyance system is under consideration to remove tank waste from the underground tanks. Pneumatic conveyance systems use high velocity air to remove small particles and solids up to about 3 inches in diameter, slurries and viscous liquid.

The pneumatic conveyance system consists of a positive displacement blower, a cyclone separator, filter and high-efficiency particulate air (HEPA) filter system. Schematic for the pneumatic conveyance system is shown in Figure A-3. The blower creates a strong suction force (i.e., air velocity inside an 8 -inch hose can reach $200 \mathrm{miles} /$ hour) at the suction nozzle. The cyclone separator removes larger particles from the air stream and the filter systems removes fine particles. All equipment, with the exception of the suction hose, will be located outside the tank environment. The waste can be conveyed to any distance as long as waste particles can be suspended in the air stream.

Pneumatic conveyance test activities were performed and a model discussed (Gates, et al., 1995). Related tank waste properties for the pneumatic conveyance are slurry density, viscosity, and surface tension. 


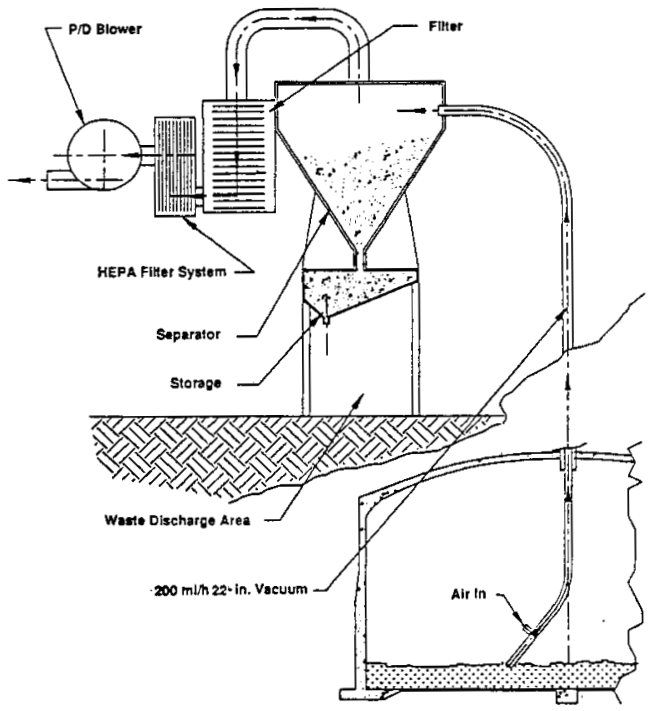

Figure A-3. Operation Scenario for the Pneumatic Conveyance System 


\section{B. WaterJets}

Waterjetting is an extension of the sluicing system and can be used to reduce leakage of radioactive waste to the environment by effectively controlling the waterjet stream. The waterjet method can locally mobilize tank waste using water (Sumers 1993). There are two types of waterjets. The first is a relatively lower pressure, high volume waterjet $(5,000$ to 20,000 $1 \mathrm{~b} / \mathrm{in}^{2}$ and 5 to $\left.15 \mathrm{gal} / \mathrm{min}\right)$. The larger mass of the water is used to dislodge the waste. The second is a higher pressure and lower volume waterjet $(35,000$ to $60,000 \mathrm{lb} / \mathrm{in}^{2}$ and 1 to $\left.6 \mathrm{gal} / \mathrm{min}\right)$. The nozzle velocity is abcut three times the speed of sound. In this case, the higher pressure is used to mobilize the waste. The waterjet can be used in conjunction with other conveyance system to remove the mobilized waste from the tank. Schematic of this scenario is shown in Figure A-4.

Key tank waste information related to waterjet cutting are tensile strength, grain or crystal size, density, porosity, fracture toughness, and hardness (Gates 1995).

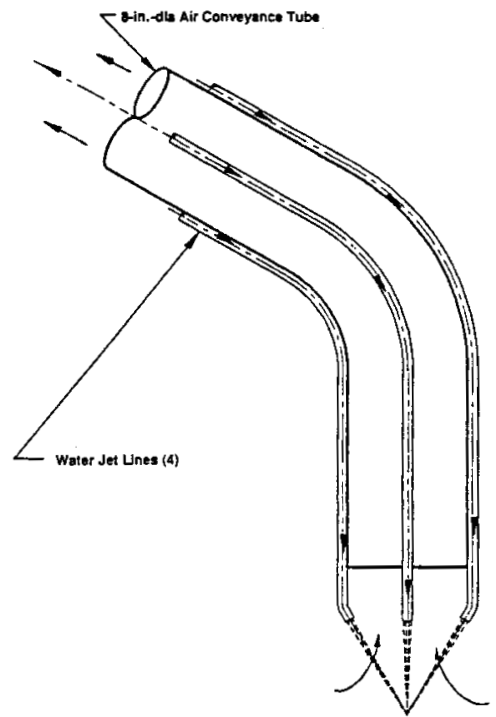

Figure A-4. Waterjets With Air Conveyance System 


\section{Scarifier}

The scarifier, as depicted in Figure A-5, is a method of waste retrieval that limits the cleanup area and is operated with a controlled input and output of water and slurry.

The scarifier system consists of a mobilization system (i.e., waterjets, air jet, steam jet, or mechanical means), rotating waterjet housing, and a vacuum conveyance system. The scarifier performs waste mobilization under a confinement dome. The waste is dislodged by the mobilization system and is removed by the vacuum conveyance system. Figure A-5 shows a scarifier system with the waterjet as the mobilization engine.

Air and waterjet scarifiers have been tested to demonstrate removal of tank waste at the Hanford Site. The air jet is effective in mobilizing soft waste, while the waterjet is effective in cutting through hard saltcake.

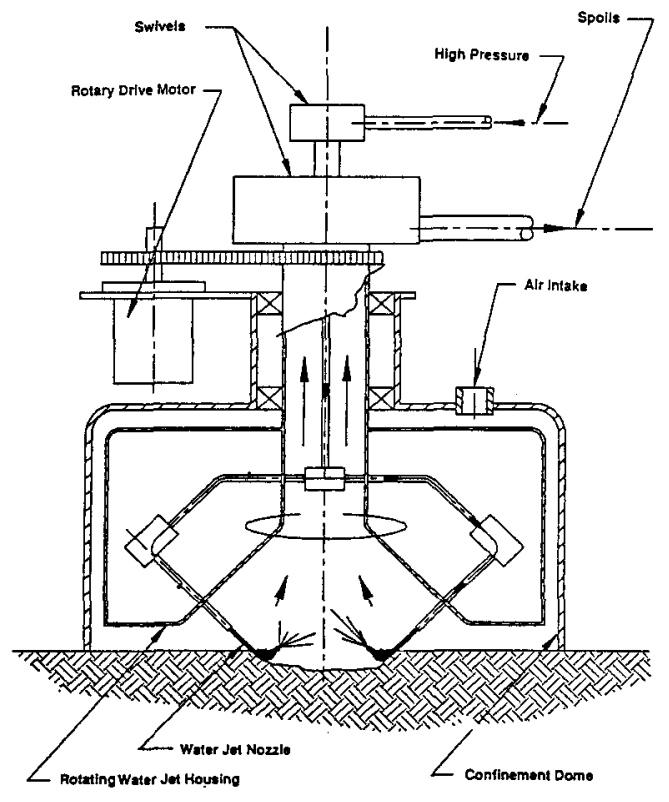

Figure A-5. Scarifier Operating Scenario 


\section{Confined Sluicing}

Confined (or contained) sluicing (Figure A-6) consists of a specially designed, hydrocrane $\mathrm{clamshell}$ and a hopper-fed air conveyance system (Summers et al. 1994). The system uses high-pressure water to further break up the solids which is air conveyed to a cyclone separator outside the tank. The set up for the air conveyance was discussed in the previous section. The clamshell bucket is capable of breaking and placing tank waste into the hopper, where high-pressure water breaks up the waste which is air conveyed from the tank.

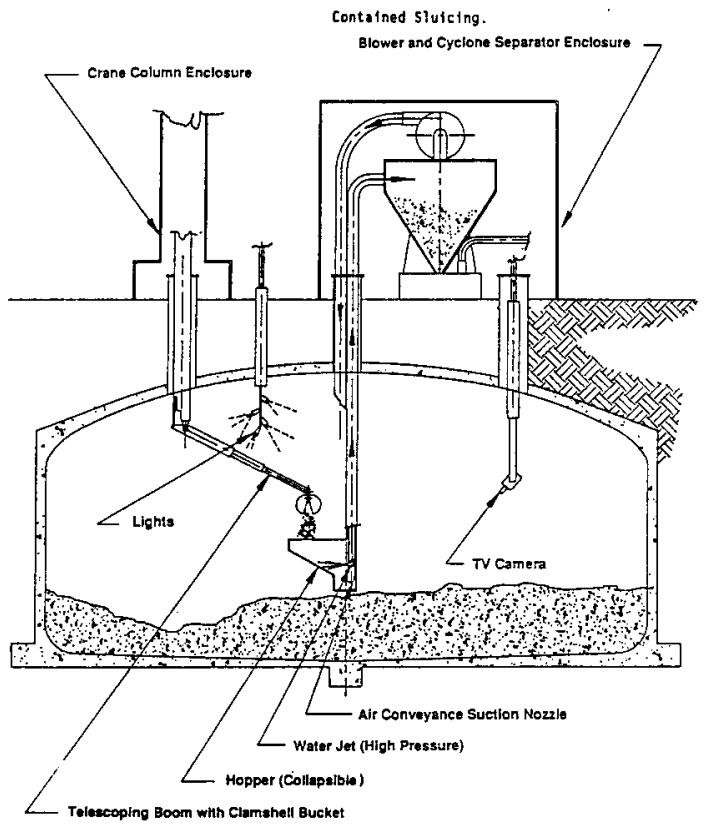

Figure A-6. Confined Sluicing 
Table A-1. Alternate System Data Needs - Scarifier Using Haterjet

\begin{tabular}{|c|c|c|c|c|}
\hline Decision or Question & Impact of Wrong Decision & $\begin{array}{l}\text { Primary } \\
\text { Decision } \\
\text { Parameter }\end{array}$ & $\begin{array}{l}\text { Type of } \\
\text { Sample }\end{array}$ & $\begin{array}{l}\text { Secondary Decision } \\
\text { Parameters }\end{array}$ \\
\hline $\begin{array}{l}\text { How many holding tanks are needed } \\
\text { for sluicing system? }\end{array}$ & $\begin{array}{l}\text { Over/under est imated number of } \\
\text { holding tanks }\end{array}$ & $\begin{array}{l}\text { Settling } \\
\text { rate of } \\
\text { slurry }\end{array}$ & $\begin{array}{l}\text { Core } \\
\text { semple }\end{array}$ & \\
\hline $\begin{array}{l}\text { How long does it take to mobilize } \\
\text { the waste using sluicing? }\end{array}$ & $\begin{array}{l}\text { Over/under estimated length of } \\
\text { time to stuice }\end{array}$ & $\begin{array}{l}\text { Settling } \\
\text { rate of } \\
\text { slurry }\end{array}$ & $\begin{array}{l}\text { Core } \\
\text { sample }\end{array}$ & \\
\hline $\begin{array}{l}\text { How much tank waste can be } \\
\text { dissolved by sluicing? }\end{array}$ & $\begin{array}{l}\text { 1. System design inadequate } \\
\text { (insufficient volume of holding } \\
\text { tanks) } \\
\text { 2. Increase volume of water } \\
\text { usage } \\
\text { 3. Over/under design of } \\
\text { evaporator capacity }\end{array}$ & $\begin{array}{l}\text { Solubility } \\
\text { Hardness }\end{array}$ & $\begin{array}{l}\text { Core } \\
\text { sample } \\
\text { In situ }\end{array}$ & \\
\hline $\begin{array}{l}\text { What is the effect of achesion on } \\
\text { the design of the retrieval } \\
\text { equipment? } \\
\text { Will waste plug pipe? }\end{array}$ & $\begin{array}{l}\text { 1. Over/under design of systems } \\
\text { 2. Add water, increase waste } \\
\text { volume to conveyance pipe }\end{array}$ & Achesion & $\begin{array}{l}\text { Core } \\
\text { sample }\end{array}$ & $\begin{array}{l}\text { PSD, Zeta } \\
\text { potential, } \\
\text { Moisture, } \\
\text { Solubility, Tensile } \\
\text { strength }\end{array}$ \\
\hline $\begin{array}{l}\text { What are the effect of the mass of } \\
\text { waste on the structural design? }\end{array}$ & $\begin{array}{l}\text { Create instability in } \\
\text { structural as well as reduced } \\
\text { performance }\end{array}$ & $\begin{array}{l}\text { Density-- } \\
\text { particle and } \\
\text { bulk }\end{array}$ & $\begin{array}{l}\text { Core } \\
\text { sample }\end{array}$ & \\
\hline & & & & \\
\hline
\end{tabular}


Table A-2. Alternate System Data Needs - Convey \& Transport

\begin{tabular}{|c|c|c|c|c|}
\hline Decision or Question & Impact of Wrong Decision & $\begin{array}{l}\text { Primary } \\
\text { Decision } \\
\text { Parameter }\end{array}$ & $\begin{array}{l}\text { Type of } \\
\text { Sample }\end{array}$ & $\begin{array}{l}\text { Secondary Decision } \\
\text { Parameters }\end{array}$ \\
\hline Will the waste plug the pipes? & $\begin{array}{l}\text { 1. Over/under design of } \\
\text { retrieval systems } \\
2 \text {. May need a new conveyance } \\
\text { system for waste } \\
3 \text {. May need new pipes }\end{array}$ & Acthesion & $\begin{array}{l}\text { Core } \\
\text { saniple }\end{array}$ & \\
\hline $\begin{array}{l}\text { What pumping power is needed to } \\
\text { convey the waste? }\end{array}$ & Recuced pumping efficiency & $\begin{array}{l}\text { Density-- } \\
\text { particle and } \\
\text { bulk }\end{array}$ & $\begin{array}{l}\text { Core } \\
\text { sample }\end{array}$ & \\
\hline $\begin{array}{l}\text { Will waste break into small } \\
\text { particles? }\end{array}$ & Waste will not mobilize & Hardhess & In situ & $\begin{array}{l}\text { Shear st.. Tensile } \\
\text { st. }\end{array}$ \\
\hline $\begin{array}{l}\text { How fast does the waste settle } \\
\text { during conveyance and transport? }\end{array}$ & $\begin{array}{l}\text { 1. Under estimated pump } \\
\text { pressure } \\
2 \text {. Pipes plugged }\end{array}$ & $\begin{array}{l}\text { Settling } \\
\text { rate of } \\
\text { slurry }\end{array}$ & $\begin{array}{l}\text { Core } \\
\text { sample }\end{array}$ & \\
\hline $\begin{array}{l}\text { Will waste stick to retrieval } \\
\text { equipment? }\end{array}$ & $\begin{array}{l}\text { 1. Over/under design of systems } \\
\text { 2. May have to add more water, } \\
\text { increase waste vol une }\end{array}$ & Adhesion & $\begin{array}{l}\text { Core } \\
\text { sample }\end{array}$ & $\begin{array}{l}\text { PSD, Zeta } \\
\text { potential, } \\
\text { Moisture, } \\
\text { Solubility, Tensile } \\
\text { strength }\end{array}$ \\
\hline
\end{tabular}


Table A-3. Alternate System Data Needs - Materjets

\begin{tabular}{|c|c|c|c|c|}
\hline Decision or Question & Impact of Wrong Decision & $\begin{array}{l}\text { Primary } \\
\text { Decision } \\
\text { Parameter }\end{array}$ & $\begin{array}{l}\text { Type of } \\
\text { Sample }\end{array}$ & $\begin{array}{l}\text { Secondary Decision } \\
\text { Parameters }\end{array}$ \\
\hline \multirow[t]{2}{*}{$\begin{array}{l}\text { For water jet end effector: } \\
\text { How much water pressure is needed? } \\
\text { How large is the water jet nozzle? } \\
\text { What is the feasibility of using } \\
\text { the waterjet? }\end{array}$} & $\begin{array}{l}\text { 1. Over design of high pressure } \\
\text { woterjet (increase cost). } \\
\text { 2. Water jet fails to mobilize } \\
\text { hard waste (under design). }\end{array}$ & $\begin{array}{l}\text { Tensile } \\
\text { strength }\end{array}$ & $\begin{array}{l}\text { In situ } \\
\text { core } \\
\text { sample }\end{array}$ & $\begin{array}{l}\text { Temperature, } \\
\text { Hardness, Shear } \\
\text { Strength }\end{array}$ \\
\hline & & $\begin{array}{l}\text { Material } \\
\text { structure } \\
\text { (porosity) }\end{array}$ & $\begin{array}{l}\text { Core } \\
\text { sample }\end{array}$ & $\begin{array}{l}\text { Crystal formation, } \\
\text { size, } \\
\text { interconnection }\end{array}$ \\
\hline
\end{tabular}

管 


\section{APPENDIX B: DESIRED TANK WASTE INFORMATION FOR DST RETRIEVAL}

Appendix B provides a preliminary identification of tank waste characterization needs for DST Retrieval design and operations identified by the Initial Tank Retrieval Systems, Project $W-211$. Significant information on the 1isted items may be found in the following DQOs: (1) Fowler 1995, (2) Slankas 1995, (3) Bloom and Nguyen 1995, and (4) Johnson 1995. The noted DQOS are listed in this appendix.

Table B-1. Desired Tank Waste Information for DST Retrieval Project

\begin{tabular}{||l|l||}
\hline $\begin{array}{l}\text { General Tank Waste } \\
\text { Information }\end{array}$ & Reason for Request \\
\hline \hline $\begin{array}{l}\text { Chemical } \\
\text { Composition(1,2) }\end{array}$ & $\begin{array}{l}\text { 1. To assure compatible materials are used in the } \\
\text { 2. To predict reaction from waste dilution }\end{array}$ \\
\hline $\begin{array}{l}\text { 3. To classify in-tank components } \\
\text { 4. To determine waste compatibility } \\
\text { Radionuclide }\end{array}$ & $\begin{array}{l}\text { 1. To perform safety analysis } \\
\text { Composition }\end{array}$ \\
\hline 2. To classify in-tank components \\
\hline Shear Strength
\end{tabular}




\section{Appendix B References}

Bloom, G. R. and Q. H. Nguyen, 1995, Characterization Data Needs for Development, Design, and Operation of Retrieval Equipment Developed Through the Data Quality Objective Process, WHC-SD-WM-DQ0-008 REV 0, Westinghouse Hanford Company, Richland, Washington.

Fowler, D. D., 1995, Data Quality Objectives for Tank Farms Waste Compatibility Program, WHC-SD-WM-DQ0-004 REV 1, Westinghouse Hanford Company, Richland, Washington.

Johnson, G. D., 1995, Flammable Gas Tank Safety Program: Data Requirements for Core Sample Analysis Deve7oped Through the Data Quality Objectives Process, WHC-SD-WM-DQO-004 REV 1, Westinghouse Hanford Company, Richland, Washington.

Kupfer, M. J., 1995, Data Needs and Attendant Data Quality Objectives for Tank Waste Pretreatment and Disposal, WHC-SD-WM-DQ0-022 REV 0, Westinghouse Hanford Company, Richland, Washington. 


\section{WHC-SD-WM-DQ0-008 REV I}

\section{APPENDIX C: INFORMAL COST AND SCHEDULE INFORMATION}

Appendix $C$ contains information on cost and schedule associated with the mixer pumps and transport system.

\section{Mixer Pump}

The default number of mixer pumps to use per tank is two. However, with use of a confirmed ECR equation and measurement of the sludge shear strength it may be possible to reduce to one mixer pump. This would save costs of manufacturing, installation, operation, maintenance, and disposal of one mixer pump. Total project cost estimates indicate an approximately cost savings of approximately $\$ 7.5 \mathrm{M}$ per pump if one instead of two mixer pumps were installed on a DST. Total project cost are estimated for the first DST to be retrieved as part of the initial tank retrieval system. The "total project cost" for 1 DST is estimated at $\$ 46.2 \mathrm{M}$ with 2 mixer pumps and $\$ 31.4 \mathrm{M}$ with no mixer pumps. The cost estimate includes design, permitting, safety, construction, installation, and reviews. The costs do not include operating and final disposal of the mixer pumps, therefore, the $\$ 7.5 \mathrm{M}$ cost savings estimate for deleting the mixer pump is conservatively low.

\section{Transport}

The transport system includes a spare transport line which will be used in case of a complete plugging of the main transport line. The worst-case cost and time estimation of $\$ 47 M$ and 1 year to replace a new transport system (material cost: $\$ 46 M+$ some redesign: $\$ 1 M)$. Cost for the transport function is based on the following estimate (Author Year).

Engineering design cost:

Remaining cost:

Total Cost:

Rebuild transport system:

Recovery of buried line:

Recovery of the diversion box:
$\$ 6.6 \mathrm{M}$

$\$ 46.1 \mathrm{M}$

$\$ 52.7 M$

$\$ 47 M$ (4.3-yr delay)

\$515K for 20-ft section

(4-mo delay time)

\$160K (2- to 5-mo delay time) 


\begin{tabular}{|c|c|c|c|c|c|}
\hline \multicolumn{6}{|c|}{ DISTRIBUTION SHEET } \\
\hline \multirow{2}{*}{$\begin{array}{l}\text { To } \\
\text { Distribution }\end{array}$} & \multirow{2}{*}{\multicolumn{3}{|c|}{$\begin{array}{l}\text { From } \\
\text { Retrieval Engineering } 73530\end{array}$}} & \multicolumn{2}{|l|}{ Page 1 of 1} \\
\hline & & & & \multicolumn{2}{|c|}{ Date $07 / 31 / 96$} \\
\hline \multicolumn{4}{|l|}{ Project Title/Work Order } & \multicolumn{2}{|l|}{ EDT No. } \\
\hline \multicolumn{4}{|c|}{$\begin{array}{l}\text { Characterization Data Needs for Development, Design, and } \\
\text { 0peration of Retrieval Equipment Developed through the Data } \\
\text { Quality Objective Process WHC-SD-WM-DQD-008 Rev 1/D2091 }\end{array}$} & \multicolumn{2}{|c|}{ ECN No. 164969} \\
\hline Name & MSIN & $\begin{array}{l}\text { Text } \\
\text { With All } \\
\text { Attach. }\end{array}$ & Text Only & $\begin{array}{l}\text { Attach.l } \\
\text { Appendix } \\
\text { Only }\end{array}$ & $\begin{array}{l}\text { EDT/ECN } \\
\text { Only }\end{array}$ \\
\hline
\end{tabular}

ONSITE

U.S. Department of Energy-

Richland Field office

B. L. Nicoll

S7 $-53 \quad x$

W. R. Wrzesinski

S7-53 $x$

ICF Kaiser Hanford Company

Q. H. Nguyen

E6-21 $x$

Westinghouse Hanford Company

D. L. Banning

G. R. Bloom

S. J. Eberlein

J. S. Hertze1

J. W. Hunt

T. J. Kelley

E. J. Kosiancic

D. L. Lamberd

R. P. Marshall

D. J. McCain

G. A. Meyer

E. M. Norquist

C. A. Rieck

J. E. Van Beek

D. J. Washenfelder

Central Files

DOE Reading Room

R2-12 $x$

H5-61 $x$

R2-12 $x$

H5-61 $x$

R2-12 $x$

S7-21 $x$

H5-61 $x$

H5-6I $x$

H5-61 $x$

R2-12 $x$

$S 2-48 \quad x$

$S 2-48 \quad x$

$S 2-48 \quad x$

S2-48 $x$

H5-27 $x$

A3-88 $x$

H2-53 $x$

\section{OFFSITE}

Department of Ecology

S. Mckinney

B5-18

$\mathrm{X}$ 